\title{
The Womack Site (41LR1), an Ancestral Caddo Settlement on the Red River in Lamar County, Texas
}

Timothy K. Perttula

Heritage Research Center, Stephen F. Austin State University

Follow this and additional works at: https://scholarworks.sfasu.edu/ita

Part of the American Material Culture Commons, Archaeological Anthropology Commons, Environmental Studies Commons, Other American Studies Commons, Other Arts and Humanities Commons, Other History of Art, Architecture, and Archaeology Commons, and the United States History Commons

Tell us how this article helped you.

This Article is brought to you for free and open access by the Center for Regional Heritage Research at SFA ScholarWorks. It has been accepted for inclusion in Index of Texas Archaeology: Open Access Gray Literature from the Lone Star State by an authorized editor of SFA ScholarWorks. For more information, please contact cdsscholarworks@sfasu.edu. 


\section{The Womack Site (41LR1), an Ancestral Caddo Settlement on the Red River in Lamar County, Texas}

\section{Creative Commons License}

\section{(c) (1) (8)}

This work is licensed under a Creative Commons Attribution-NonCommercial 4.0 International License 


\title{
The Womack Site (41LR1), an Ancestral Caddo Settlement on the Red River in Lamar County, Texas
}

\author{
Timothy K. Perttula
}

\section{INTRODUCTION}

The Womack site (41LR1) is an ancestral Caddo settlement situated on an alluvial terrace in a horseshoe bend of the Red River in north central Lamar County in East Texas (Figure 1). Harris et al. (1965) completed the analysis and study of their 1938-mid-1960s investigations at the site, but the findings from the earlier archaeological investigations conducted at the site by the University of Texas (UT) in 1931 have not been previously published. In this article I discuss the 1931 investigations by UT at the Womack site, and also summarize the character of the artifact assemblage recovered at the site during this work. Lastly, I consider the occupational character and settlement history of the Womack site - particularly its history of settlement by ancestral Caddo peoples - and define a Womack phase for the ca. A.D. 1690-1750 archeological components at the Womack, Sanders (41LR2), Goss Farm (41FN12), and Harling (41FN1) sites along the upper Red River and the Gilbert (41RA13) and Pearson (41RA5) sites in the upper Sabine River basin.

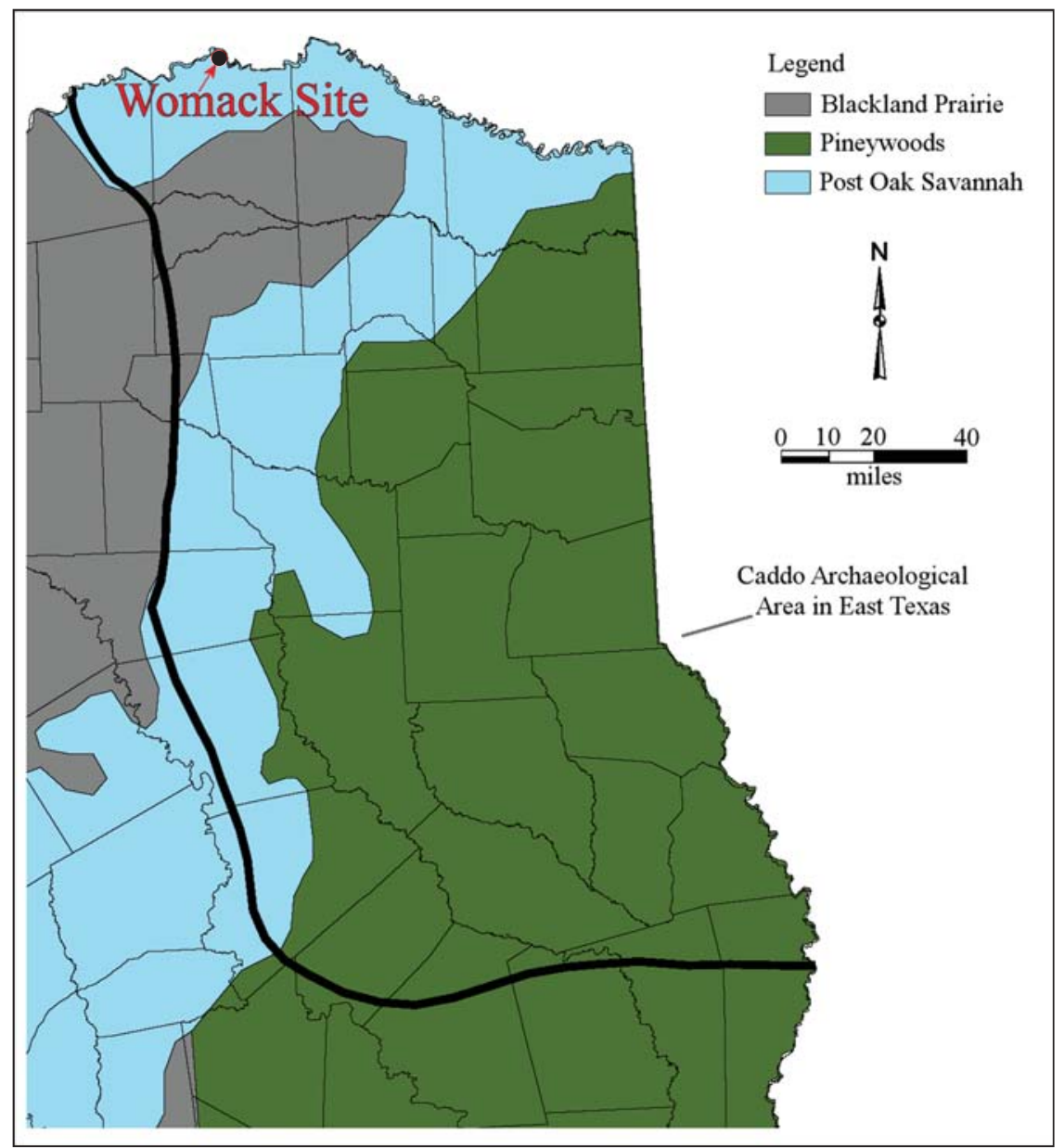

Figure 1. Location of the Womack site in East Texas. 


\section{PAST ARCHAEOLOGICAL INVESTIGATIONS}

UT archaeologists conducted investigations at the Womack site between August 29-September 4, 1931 (Pearce and Jackson 1931), the year following the landowner plowing up a burial with several associated ceramic vessels. In addition to obtaining surface collections, and identifying four distinct midden deposits, the UT work also consisted of the excavation of eight burials in three different parts of the site (Figure 2).

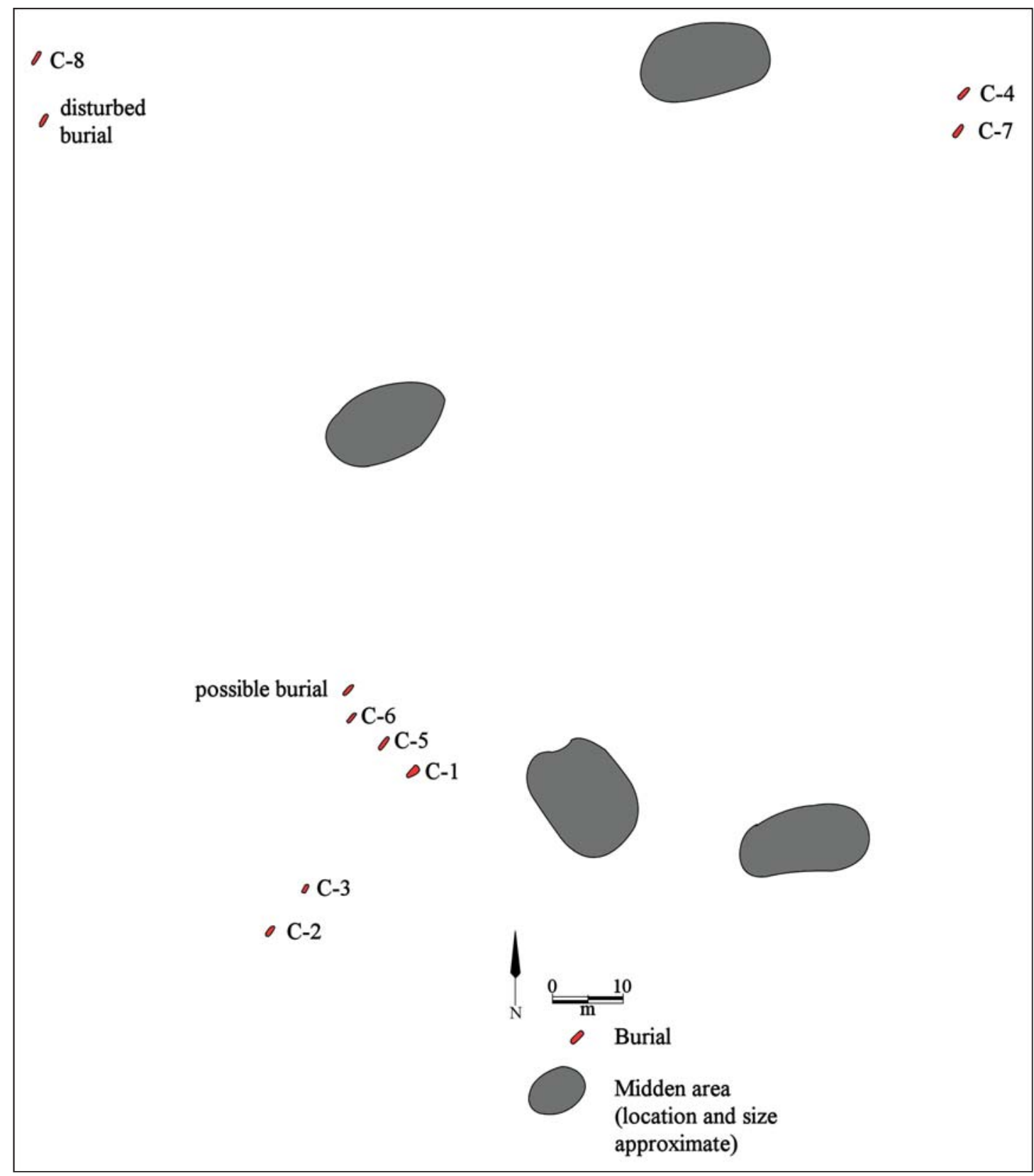

Figure 2. Location of midden deposits and burials excavated by UT at the Womack site.

The burials include adult men and women as well as children (Table 1). Another possible burial, just north of burial C-6 (see Figure 2), was marked by the recovery of two ceramic vessels found together at ca. $36 \mathrm{~cm}$ bs, and there was a disturbed burial ca. $9 \mathrm{~m}$ from burial C- 8 . The disturbed burial had a bison scapula hoe in association. 
Table 1. Characteristics of burials excavated by UT at the Womack site.

\begin{tabular}{llll}
\hline Burial No. & Orientation & Age and Sex & Funerary Offerings \\
\hline C-1 & extended & child & none \\
C-2 & extended & female, ca. 19 & none \\
C-3 & extended & female, ca. 40 & 4 ceramic vessels \\
C-4 & semi-flexed & male, ca. 50 & none \\
C-5 & extended & child, ca. 3 & 4 ceramic vessels; 2 arrow points; \\
& & & 1 lithic knive; 1 lithic scraper; 1 iron \\
& & & knive; 19 glass beads (14 blue and 5 \\
C-6 & extended & female, ca. 55 & nhite, small) \\
C-7 & extended & female, ca. 50 & none \\
C-8 & flexed & UID & 4 lithic scrapers; 1 lithic drill \\
\hline
\end{tabular}

UID=unidentified

Ceramic vessels in Burial C-3 include a Canton Incised bowl $(11.4 \mathrm{~cm}$ in diameter), and three plain bowls and jars. The ceramic vessels in Burial C-5 include a small jar with handles, a plain bottle $(7.6 \mathrm{~cm}$ in height), a Womack Engraved carinated bowl with a Motif C design, and another Womack Engraved (Motif A) bowl with engraved triangles pendant from just under the vessel lip.

In addition to the ceramic vessels in Burials $\mathrm{C}-3$ and $\mathrm{C}-5$, there are sections of two vessels in the TARL collections that may be from the previously mentioned possible burial; the sherd vessel sections are not labeled as coming from a burial. Both vessel sections are from large (31.0-32.0 orifice diameter) Womack Engraved carinated bowls with Motif A and Motif D decorative elements, respectively (Figure 3a-c). A plain bowl in the collection from the Womack site, with a $16.3 \mathrm{~cm}$ orifice diameter, was purchased by UT from the landowner.

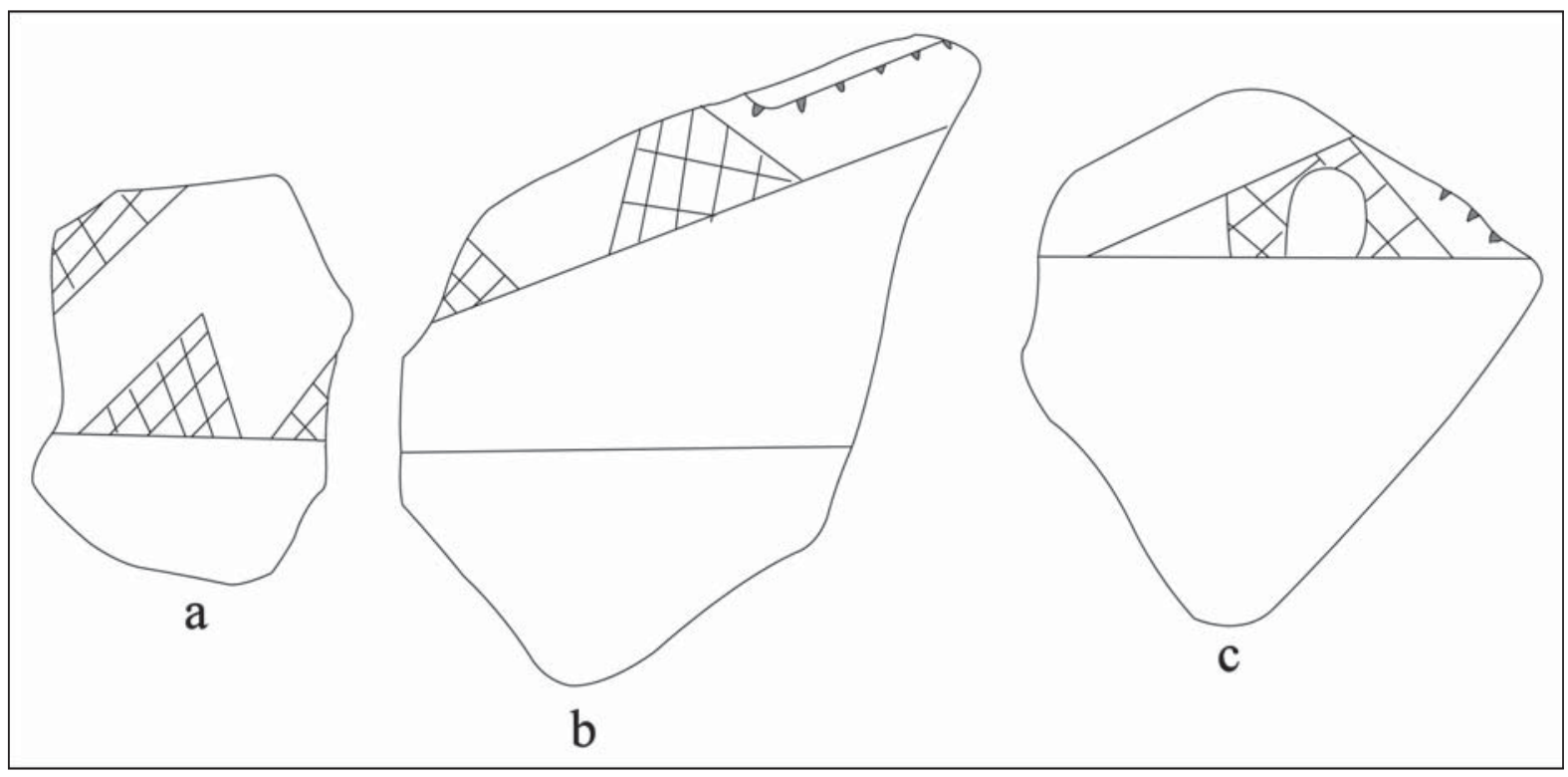

Figure 3. Womack Engraved carinated bowl vessel sections found between ca. $23-51 \mathrm{~cm}$ bs at the Womack site: a, Motif A vessel section; b-c, Motif D vessel section. 
Work by Harris et al. (1965:287), and members of the Dallas Archeological Society, over the years at the Womack site indicates that its archaeological deposits consist of "midden debris, burials, and probable house remains buried in a sandy layer which appears to average about 18 inches thick." These archaeological deposits covered about 30 acres of an alluvial terrace that had been under cultivation since the early 20th century. Harris et al. (1965:288) "made surface collections, dug a number of small test pits, and salvaged burials disturbed by plowing or fence building." None of the possible house features-marked by "circular concentrations of bone, shell, artifacts, burned daub, and stone" - at Womack were investigated in any detail by Harris et al. (1965:289).

Four ancestral Caddo burials were excavated by Harris et al. (1965:289-291) at the Womack site. These burials (Burials 1-4) had been interred in midden deposits. The deceased individuals had been buried in an extended supine position with their heads to the north or northeast, and facing south or southwest. There were associated funerary offerings with Burials 1-3, and they included only 12 ceramic vessels of the following types: Emory Punctated-Incised $(n=3)$, Hudson Engraved $(n=1)$, Natchitoches Engraved $(n=1)$, Simms Engraved $(n=3)$, and Womack Engraved $(n=4)$ (Harris et al. 1965:Figures 4 and 5a-e). These vessels are associated with the ca. A.D. 1700-1730 occupation at the Womack site.

A large assemblage of artifacts were recovered in the Harris et al. (1965) investigations beyond the ceramic vessels associated with Burials 1-3. This included 2570 ceramic sherds from "grit-tempered" and shell-tempered vessels, a clay figurine fragment, and ceramic elbow pipes; there were also fragments of three stone pipes. There were also conch-shell beads $(n=3)$, seven stone beads, a quartz crystal, two marine shell ornaments, and native-made brass beads $(n=15)$ and tinklers $(n=77)$. The substantial lithic assemblage from the Womack site was comprised of arrow points $(n=928)$, mostly of the Fresno type, knives $(n=89)$, scrapers $(n=872)$, gravers $(n=14)$, native-made gunflints $(n=23)$, celts $(n=9)$, manos $(n=6)$, abraders $(n=14)$, and hammerstones $(\mathrm{n}=28)$.

The European trade goods recovered at the Womack site by Harris et al. (1965:307-357) include glass beads ( $n=2123)$, a variety of gun parts from French flintlocks, gunflints $(n=8)$, lead bullets $(n=6)$, lead shot $(n=2)$, a possible sword guard, iron axes and wedges $(n=7)$, iron knives $(n=7)$, an iron awl, horse trappings, a strike-a-light, a possible piece of armor, many brass kettle fragments, hawk bells, brass and lead discs, a disc-shaped medal, brass buttons $(\mathrm{n}=10)$, and mirror glass sherds. Also recovered was a single wheel-made vessel (Harris et al. 1965:Figure 23), possibly of faience or majolica. These trade goods date from ca. A.D. 1700-1730.

\section{ARTIFACT ASSEMBLAGE AT THE TEXAS ARCHEOLOGICAL RESEARCH LABORATORY}

There is a large and diverse artifact assemblage from the Womack site in the collections at the Texas Archeological Research Laboratory (TARL). This includes Paleoindian to Woodland period dart points, bifaces, and ground stone tools, as well as many arrow points, scrapers, beveled knives, and other flake tools, plus native-made gunflints. The ceramic assemblage includes 10 vessels from the 1931 UT investigations and an assortment of plain ware, utility ware, and fine ware sherds, as well as ceramic long-stemmed and elbow pipe sherds and two almost complete pipes. There are 14 shell and bone beads in the assemblage. Lastly, the artifact assemblage from the Womack site includes a number of early 18th century European trade goods, principal among them glass beads, brass tinklers, knives, and gun parts. 


\section{Chipped Stone Tools at the Womack Site}

\section{Dart Points}

There are 51 dart points and dart point fragments in the chipped stone tools from the Womack site (Table 2). Including the two preforms, almost 70 percent of the dart points are contracting stem Gary points. In combination with the cf. Darl, Godley, and Kent points from the site in the collections, the dart assemblage at the site suggests a substantial Woodland period use (ca. 2500-1250 years B.P.) of the Womack site.

Table 2. Dart points from the Womack site.

\begin{tabular}{|c|c|c|c|c|}
\hline \multirow[b]{2}{*}{ Type } & \multicolumn{3}{|c|}{ Raw Material } & \multirow[b]{2}{*}{$\mathrm{N}$} \\
\hline & Red River chert & Nov. & Qtz. & \\
\hline cf. Darl & 1 & - & - & 1 \\
\hline Gary & 20 & 3 & 10 & 33 \\
\hline Godley & 1 & - & - & 1 \\
\hline Keithville & 1 & - & - & 1 \\
\hline Kent & 1 & - & 1 & 2 \\
\hline Morrill & 1 & - & - & 1 \\
\hline Scottsbluff & 1 & - & - & 1 \\
\hline Trinity & 1 & - & - & 1 \\
\hline Williams & - & 1 & 1 & 2 \\
\hline Yarbrough & 2 & - & 1 & 3 \\
\hline $\begin{array}{l}\text { UID expanding stem with } \\
\text { concave base }\end{array}$ & 1 & - & - & 1 \\
\hline $\begin{array}{l}\text { UID rectangular stemmed with } \\
\text { basal grinding }\end{array}$ & 1 & - & - & 1 \\
\hline blade fragments & - & - & 1 & 1 \\
\hline preforms (for Gary points) & 2 & - & - & 2 \\
\hline Totals & 33 & 4 & 14 & 51 \\
\hline
\end{tabular}

Nov.=novaculite; Qtz.=quartzite; UID=unidentified

Other aboriginal uses of the Womack site occurred during the Late Paleoindian period (ca. 10,000 years B.P.), as evidenced by single examples of Keithville and Scottsbluff points. The one rectangular-stemmed dart point with basal grinding may also be associated with this component (see Table 2). The remaining dart points (Morrill, Trinity, Williams, and Yarbrough, plus one unidentified expanding stem point) are part of a Late Archaic (ca. 5000-2500 years B.P.) occupation(s).

Approximately 65 percent of the dart points are made from Red River gravel cherts (see Table 2). Another 27 percent are made from local quartzites, and the remaining 8 percent are made from novaculite. Most of the novaculite and quartzite dart points are Gary points.

\section{Arrow points}

A total of 140 arrow points and arrow point fragments are in the Womack site chipped stone tool assemblage (Table 3). The majority of the arrow points in the collection (about 82 percent of the identifiable 
points) are triangular arrow points that compare favorably to both Late Caddo to Early Historic Caddo Fresno and Maud point styles (see Harris et al. 1965:Figure 1b-e). This is the principal arrow point style in other Womack phase sites on the Red River and on components such as Gilbert and Pearson on the Sabine River. The one Washita arrow point is likely associated with this early historic occupation at the Womack site, based on its recovery from protohistoric/early historic sites in the Southern Plains (Duncan et al. 2007:144).

Table 3. Arrow points from the Womack site.

\begin{tabular}{lcccc}
\hline & & Raw Material & \\
Type & Red River chert & Nov. & Qtz. & N \\
\hline Alba & 2 & - & - & 2 \\
Bonham & 7 & - & - & 7 \\
cf. Fresno/Maud & 89 & 6 & 1 & 96 \\
Keota & 4 & - & - & 4 \\
Sallisaw & 4 & - & - & 6 \\
Scallorn & 1 & - & - & 1 \\
Washita & $1 *$ & - & 2 & 1 \\
triangular preform & 8 & - & 1 & 13 \\
blades/tip fragments & 12 & 8 & 4 & 140 \\
\hline Totals & 128 & & & 13 \\
\hline
\end{tabular}

*Alibates; Nov.=novaculite; Qtz.=quartzite

There are earlier arrow point styles that are probably associated with a Sanders phase occupation (ca. A.D. 1100-1300) at the Womack site. These include the Alba, Bonham, Keota (Brown 1996:444), Sallisaw (Brown 1996:442; one Sallisaw point is illustrated by Harris et al. [1965:Figure 11] from the Womack site, but it is classified as a Scallorn sattler point), and Scallorn types; these comprise approximately 16 percent of the arrow point assemblage (see Table 3).

The pre-A.D. 1300 arrow points are made from both Red River cherts (90 percent) and novaculite (10 percent). There is more raw material variety represented in the cf. Fresno and Washita points at the Womack site, but Red River cherts comprise 91.8 percent of this sample, little different from the earlier arrow point styles (see Table 3). Novaculite represents 6.2 percent, quartzite 1.0 percent, and Alibates only 1.0 percent.

\section{Scrapers}

Scrapers are particularly abundant in the Womack site chipped stone tools (Table 4). Most notably, end scrapers and end-side scrapers comprise 43 and 33 percent, respectively, of the assemblage. Harris et al. (1965:294 and Figure 2a-d) document a large sample of end scrapers, but they note that side scrapers are relatively abundant at the Womack site but not at the later Pearson site; they suggest that side scrapers may "represent an early Norteno Focus trait," that is, side scrapers are present in pre-A.D. 1730 historic sites but not at later historic sites in the region. Approximately 25 percent of the scrapers from the Womack site in the UT collections are side scrapers, including side scrapers with two working edges (Table 4). 
Table 4. Scrapers from the Womack site.

\begin{tabular}{lcccc}
\hline Type & \multicolumn{3}{c}{ Raw Material } \\
& Red River cherts & Qtz. & Nov. & N \\
\hline end scrapers & 58 & - & 1 & 59 \\
end-side scrapers & 44 & 1 & - & 45 \\
side scrapers & 21 & - & - & 21 \\
side scraper with bilateral & 12 & 1 & 13 \\
working edges & 135 & 2 & 138 \\
\hline Totals & & & \\
\hline
\end{tabular}

Qtz.=quartzite; Nov.=novaculite

About 98 percent of the scrapers from the Womack site are made from Red River gravel cherts, a highquality lithic raw material. About 0.7 percent of the scrapers are made from novaculite, and 1.4 percent are made from local quartzite.

\section{Drills and Perforators}

Drills (with bifacially chipped bits, Figure 4a-b) and perforators (unifacially chipped bits) are also among the chipped stone tools in the assemblage. There are eight drills (six of Red River cherts and two of quartzite) and four perforators (three of Red River cherts and one of quartzite) (see also Harris et al. 1965:Figure 3d-e).

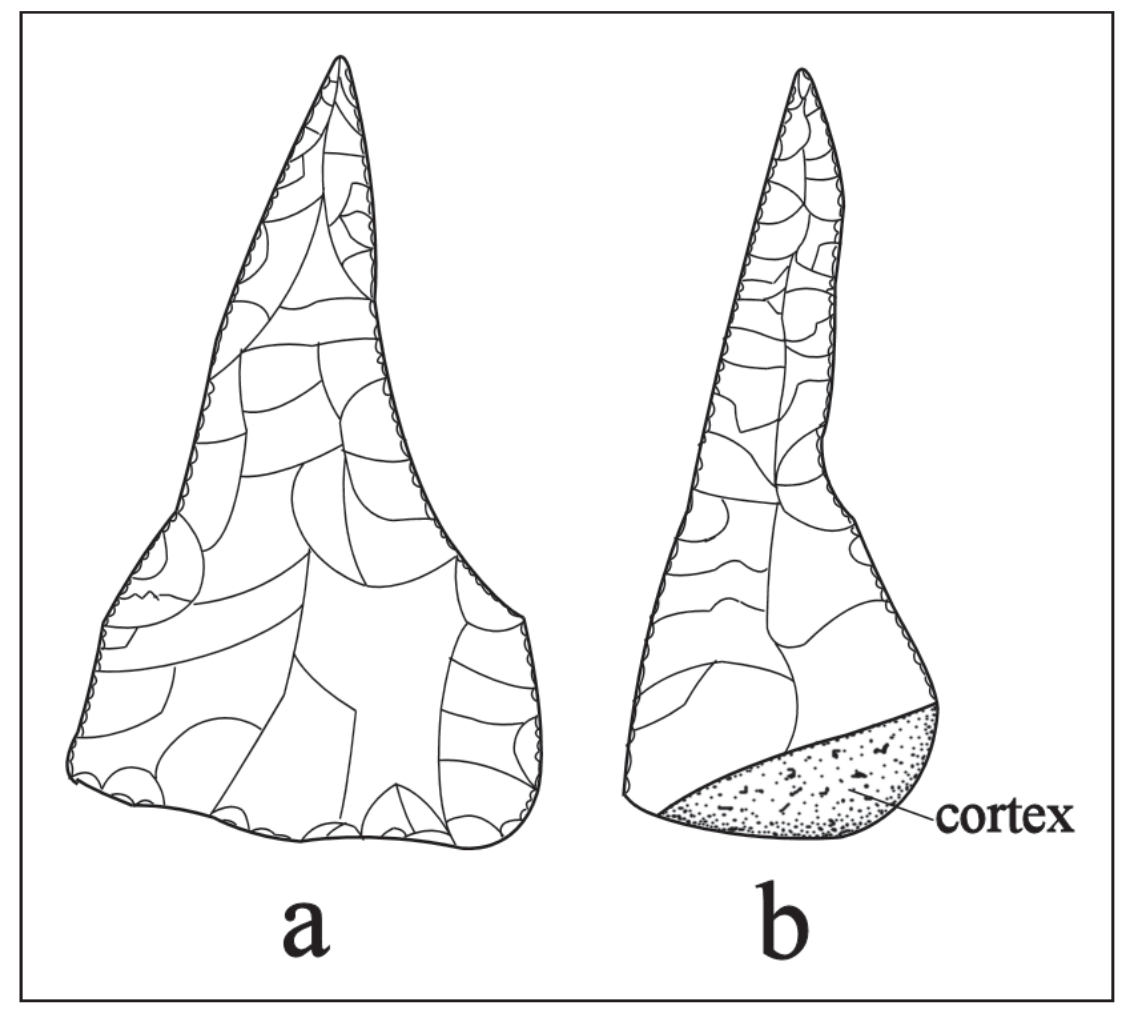

Figure 4. Drills from the Womack site. 


\section{Knives}

The knives include a quartzite medial fragment and three extensively resharpened beveled knives (Figure 5a-b). The beveled knives are made from Red River cherts (see Harris et al. 1965:Figure 1p). There are also eight possible large flake knives with lateral and unifacial use-worn and retouched areas. These tools are made from Red River cherts $(n=6)$, novaculite $(n=1)$, and quartzite $(n=1)$.

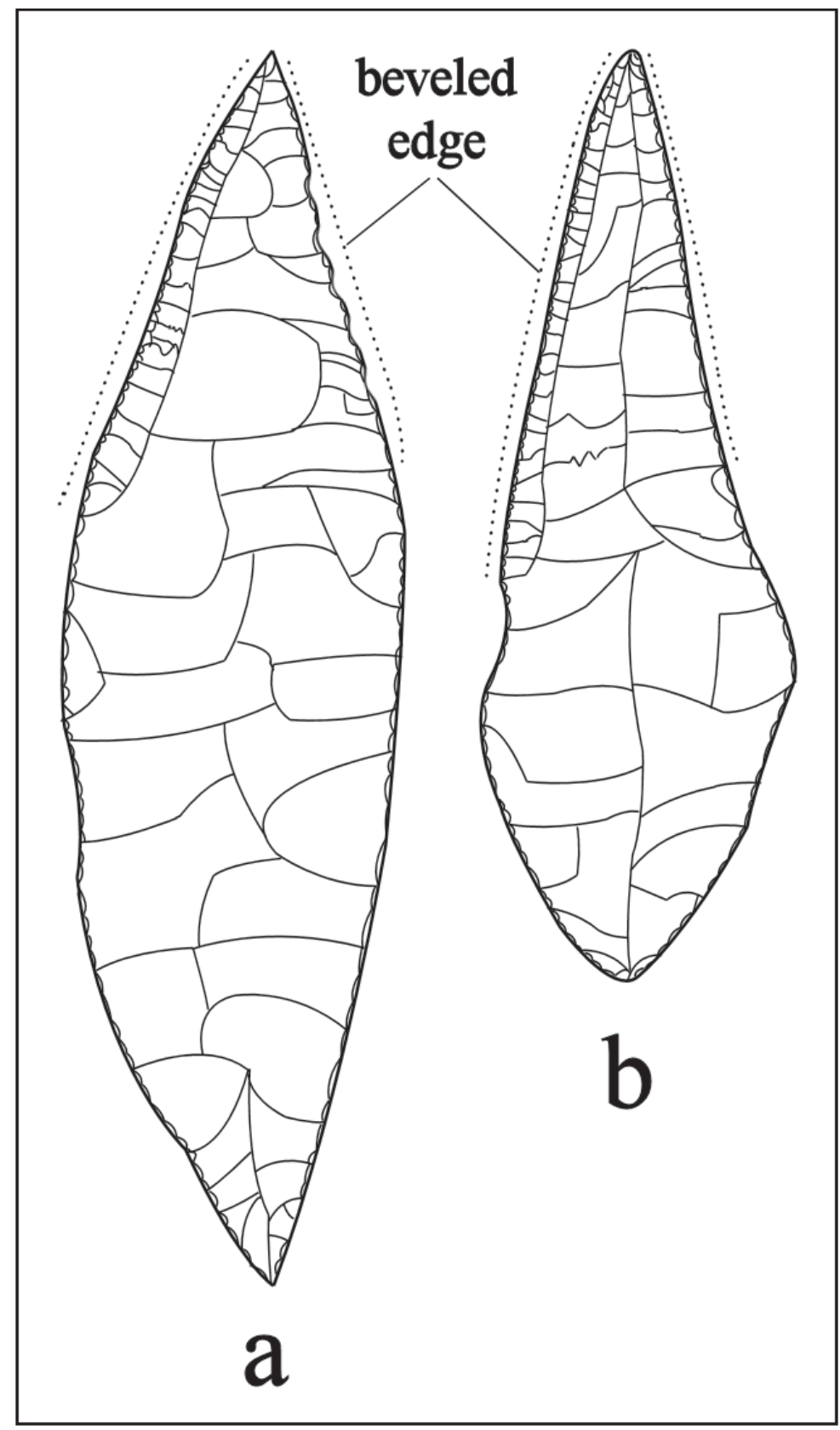

Figure 5. Beveled knives from the Womack site.

\section{Bifaces}

There are a number of biface fragments in the assemblage that represent discarded early to late stages of dart point manufacture. The two early stage bifaces are made from Red River chert and novaculite; the 
eight mid-stage bifaces and biface fragments (with no cortex, but thick and irregular in shape) are made from Red River cherts $(n=5)$, quartzite $(n=2)$, and petrified wood $(n=1)$. The final stage biface, made from quartzite, has sinuous edges and no cortical remnants.

\section{Expedient Flake Tools}

Most of the expedient flake tools (77 percent) from the Womack site have only one lateral area of use wear/retouch (Table 5), with the remainder having two or more lateral areas of use wear/retouch. These tools are overwhelmingly made from Red River gravel cherts, but with minor use of local quartzite (1.6 percent) and novaculite (3.2 percent).

Table 5. Flake tools from the Womack site.

\begin{tabular}{lcccc}
\hline & & Raw Material & \\
Type & Red River cherts & Nov. & Qtz. & N \\
\hline unilateral flake tool & 46 & 1 & 1 & 48 \\
bilateral flake tool & 12 & 1 & - & 13 \\
multilateral flake tool & 1 & - & - & 1 \\
\hline Totals & 59 & 2 & 1 & 62 \\
\hline Qtz.=quartzite; Nov.=novaculite & & &
\end{tabular}

Double-bitted axes

There are two Woodland period percussion-flaked double-bitted axes in the collections, one made from ferruginous sandstone and the other made from hematite. Schambach (2002) and Turner (2006) indicate that these axes were used between ca. 400 B.C. and A.D. 500. Harris et al. (1965:Figure 1r) illustrate another double-bitted axe from the Womack site.

\section{Native-made gunflints}

The eight native-made gunflints from the Womack site are made from Red River cherts $(n=6)$ and novaculite $(\mathrm{n}=2)$. They are square to rectangular in shape and biconvex in cross-section (see Harris et al. 1965:Figure a-g).

\section{Ground Stone Tools}

The ground stone tools include five manos (two of quartzite and three of sandstone), one of which was recovered between ca. $20-40 \mathrm{~cm}$ bs in the UT excavations, along with one ferruginous sandstone grinding slab, a quartzite mano-hammerstone, one quartzite hammerstone, and two pitted stones. The pitted stones are made from quartzite and ferruginous sandstone. There are also two polished pebbles in the collection, and six rectangular sandstone grooved abraders, possibly used as arrow shaft abraders (see Harris et al. 1965:298 and Figure 3i).

There are 10 celt fragments from the Womack site, with polished bit ends and rounded poll ends (see also Harris et al. 1965:Figure 3g-h). They are made from siliceous shale $(n=6)$, tuff $(n=1)$, an unidentified metamorphic rock $(n=1)$, quartzite $(n=1)$, and quartzitic sandstone $(n=1)$ (Figure 6). 


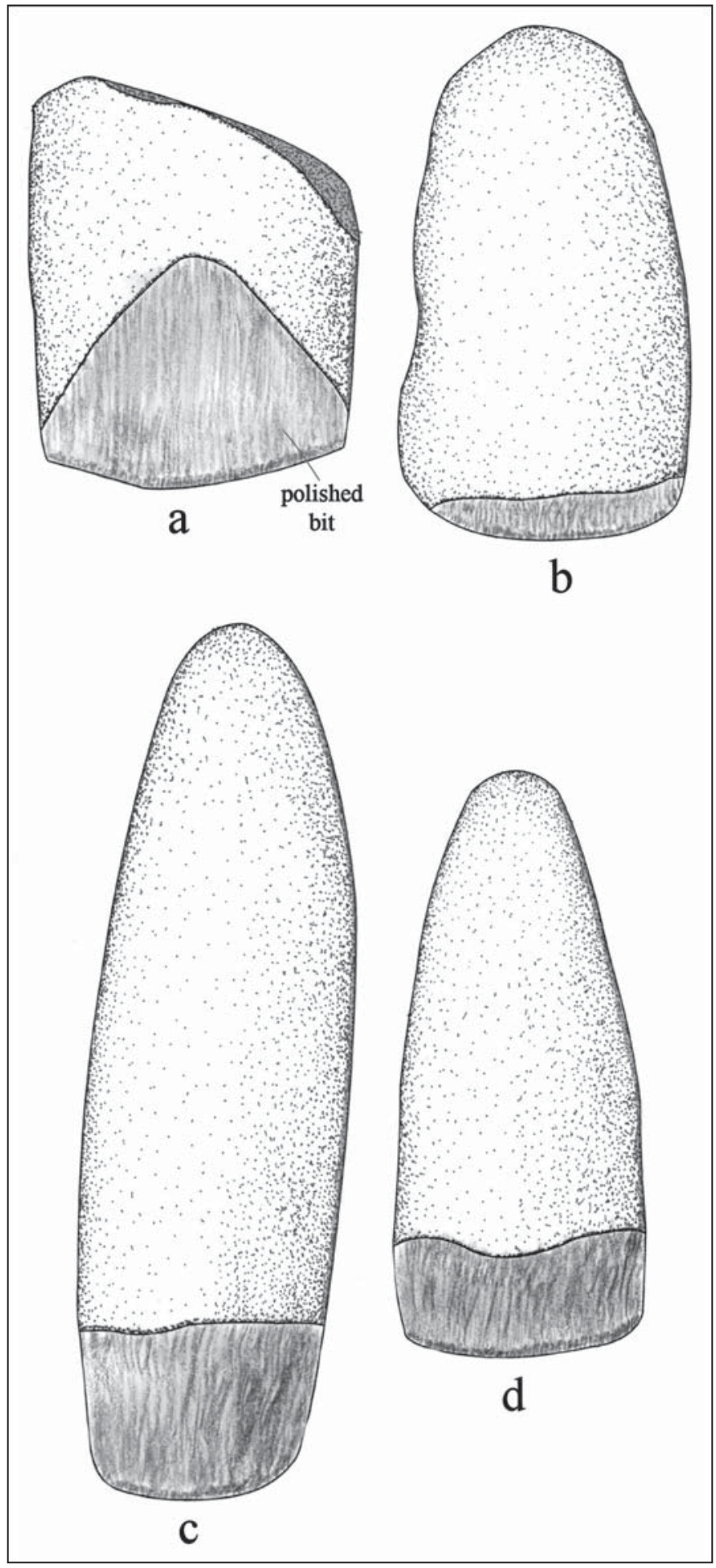

Figure 6. Celt fragments from the Womack site.

\section{Ceramic Vessels}

None of the ceramic vessels recovered in the burial excavations have been examined as part of this study, other than to examine vessel inventory information in the TARL files. However, there are sections of two grog-tempered Womack Engraved carinated bowls that were recovered in the midden excavations, 
from depths of 23-51 cm bs; they do not appear conclusively to have been found with burial features. The first vessel section (nine sherds) has a Motif A decoration on the rim (see Story et al. 1965:Figure 49a), with upper and lower rows of cross-hatched pendant triangles (see Figure 3a). The second vessel section (20 sherds) has a Motif D decoration on the rim (see Figure 3b), and the exterior surface also has a red slip. Motif D includes diagonal to curvilinear scroll lines with tick marks, large cross-hatched engraved pendant triangles on the scroll line, and cross-hatched engraved upper and lower scroll fill zones with negative ovals in the scroll fill zones.

\section{Ceramic Sherds}

There are 1314 plain rim, body, and base sherds in the assemblage from the UT investigations at the Womack site. A sample of 896 plain sherds (68 percent pf all the plain sherds) were sorted into rim, body, and base sherds, and then categorized by temper type, including grog, bone, and shell, the principal temper categories in East Texas ceramic wares (Perttula 2013). The same was done for the utility ware $(n=199)$ and fine ware $(\mathrm{n}=155)$ rim and body sherds. Of the sherds analyzed for temper, 71.4 percent are from grogtempered vessels; 10.0 percent are from bone-tempered vessels; and 18.5 percent are from shell-tempered vessels (Table 6). The plain to decorated sherd ratio for the assemblage as a whole is 3.71 .

Table 6. Temper in the ceramic wares at the Womack site.

\begin{tabular}{|c|c|c|c|c|c|c|c|c|c|c|}
\hline \multirow[b]{3}{*}{ Ware } & \multicolumn{9}{|c|}{ Temper } & \multirow[b]{3}{*}{$\mathrm{N}$} \\
\hline & & Grog & & & Bone & & & Shell & & \\
\hline & rim & body & base & rim & body & base & rim & body & base & \\
\hline Plain Ware* & $44+$ & 561 & $37 * *$ & 4 & 81 & 4 & 25 & 137 & 3 & 896 \\
\hline Fine Ware & 29 & 102 & - & 2 & 14 & - & 1 & 7 & - & 155 \\
\hline Utility Ware & 24 & 96 & - & 5 & 16 & - & 10 & 48 & - & 199 \\
\hline Totals & 97 & 759 & 37 & 11 & 111 & 4 & 36 & 192 & 3 & 1250 \\
\hline
\end{tabular}

* this includes 24 plain sherds from Burials C-4, C-6, C-8, and the disturbed burial

**includes one spindle whorl

+ two rims have scalloped lips

Among the fine wares, the proportion of grog-tempered vessels is 84 percent, compared to 10.3 percent for bone-tempered sherds, and only 5.2 percent for the shell-tempered sherds. By contrast, among the utility wares, only 60.3 percent are from grog-tempered vessels, 10.6 percent are from bone-tempered vessels, and 29.2 percent are from shell-tempered vessels (see Table 6); the significant increase in shell-tempered utility wares compared to shell-tempered fine wares in the assemblage is notable.

Of the 144 rim sherds in the assemblage, more than 50.7 percent are from plain wares, which highlights the fact that sherds from plain ware bowls, carinated bowls, jars, and bottles are well represented at the Womack site during the ancestral Caddo occupations. Fine wares comprise 22.2 percent of the rims, and 27.0 percent of the rims are from utility ware vessels (see Table 6). The proportion of plain rims to the decorated rims is 44:53 for the grog-tempered sherds, 4:7 for bone-tempered sherds, and 25:11 for shell-tempered sherds. Plain shell-tempered vessels are thus disproportionally overrepresented in the Womack site ceramics compared to both the grog- and bone-tempered vessels.

One grog-tempered base sherd was reworked into a spindle whorl with a centrally-located drilled perforation. 


\section{Utility Ware Sherds}

Utility ware sherds are from vessels used for cooking and storage tasks at the site, almost always jars. The decorations are done on these vessels while they were still wet (i.e., before firing). These vessels are more coarsely tempered, and have thicker and more durable walls than most of the fine wares. They often have extensive areas of charred organic residues and sooting from use over an open fire.

About 56.2 percent of the decorated sherds in the Womack site assemblage are from utility wares; that is, vessels that were decorated with wet-paste methods and elements, including brushed, incised, punctated, etc. (see Table 6). The most common decorative methods in the utility wares have incised line elements (56.8 percent), as well as tool punctated (12.1 percent), fingernail punctated (10.6 percent), brushed ( 7.0 percent), and appliqued (5.5 percent) elements (Table 7).

Table 7. Decorative methods and elements represented in the utility ware sherds from the Womack site.

\begin{tabular}{|c|c|c|c|c|c|c|c|}
\hline \multirow{2}{*}{$\begin{array}{l}\text { Decorative method } \\
\text { and elements }\end{array}$} & \multicolumn{2}{|c|}{ Grog } & \multicolumn{2}{|c|}{ Bone } & \multicolumn{2}{|c|}{ Shell } & \multirow[b]{2}{*}{$\mathrm{N}$} \\
\hline & rim & body & rim & body & rim & body & \\
\hline \multicolumn{8}{|l|}{ Appliqued } \\
\hline node/nodes & 1 & - & 1 & - & 1 & 1 & 4 \\
\hline $\begin{array}{l}\text { horizontal fillet at rim-body } \\
\text { juncture }\end{array}$ & - & - & - & - & 1 & - & 1 \\
\hline parallel appliqued ridges & - & - & - & - & - & 1 & 1 \\
\hline straight appliqued fillet & - & 1 & - & - & - & 3 & 4 \\
\hline straight appliqued ridge & - & 1 & - & - & - & - & 1 \\
\hline Subtotal & 1 & 2 & 1 & - & 2 & 5 & 11 \\
\hline \multicolumn{8}{|l|}{ Appliqued-Punctated } \\
\hline $\begin{array}{l}\text { appliqued node and row of } \\
\text { diagonal fingernail punctates }\end{array}$ & 1 & - & - & - & - & - & 1 \\
\hline $\begin{array}{l}\text { appliqued node and row of } \\
\text { diagonal tool punctates }\end{array}$ & - & - & - & - & 1 & - & 1 \\
\hline Subtotal & 1 & - & - & - & 1 & - & 2 \\
\hline \multicolumn{8}{|l|}{ Brushed } \\
\hline parallel brushing & - & 6 & - & 1 & - & 7 & 14 \\
\hline \multicolumn{8}{|l|}{ Brushed-Incised } \\
\hline $\begin{array}{l}\text { parallel brushing with overlying } \\
\text { parallel incised lines }\end{array}$ & - & 1 & - & - & - & - & 1 \\
\hline $\begin{array}{l}\text { parallel brushed with overlying } \\
\text { straight incised line }\end{array}$ & - & - & - & 1 & - & - & 1 \\
\hline Subtotal & - & 1 & - & 1 & - & - & 2 \\
\hline \multicolumn{8}{|l|}{ Brushed-Punctated } \\
\hline $\begin{array}{l}\text { parallel brushed with tool } \\
\text { punctated row through the } \\
\text { brushing }\end{array}$ & - & 1 & - & - & - & - & 1 \\
\hline
\end{tabular}


Table 7. Decorative methods and elements represented in the utility ware sherds from the Womack site, cont.

\begin{tabular}{|c|c|c|c|c|c|c|c|}
\hline \multirow{2}{*}{$\begin{array}{l}\text { Decorative method } \\
\text { and elements }\end{array}$} & \multicolumn{2}{|c|}{ Grog } & \multicolumn{2}{|c|}{ Bone } & \multicolumn{2}{|c|}{ Shell } & \multirow[b]{2}{*}{$\mathrm{N}$} \\
\hline & rim & body & rim & body & rim & body & \\
\hline \multicolumn{8}{|l|}{ Incised } \\
\hline cross-hatched incised lines & - & 4 & - & - & - & - & 4 \\
\hline curvilinear incised lines & - & 1 & - & - & - & - & 1 \\
\hline diagonal lines, L-R & 1 & - & - & - & - & - & 1 \\
\hline diagonal opposed lines & 2 & 3 & 1 & 2 & - & 2 & 10 \\
\hline horizontal lines & 4 & - & 1 & 2 & 1 & - & 8 \\
\hline horizontal and diagonal lines & - & 2 & - & - & - & - & 2 \\
\hline horizontal and vertical lines & 2 & - & - & - & - & - & 2 \\
\hline $\begin{array}{l}\text { horizontal and cross-hatched } \\
\text { lines }\end{array}$ & - & 1 & - & - & - & - & 1 \\
\hline parallel lines & - & 37 & - & 5 & - & 32 & 74 \\
\hline straight lines & - & 7 & - & - & - & - & 7 \\
\hline vertical lines & 2 & 1 & - & - & - & - & 3 \\
\hline Subtotal & 11 & 56 & 2 & 9 & 1 & 34 & 113 \\
\hline \multicolumn{8}{|l|}{ Incised-Appliqued } \\
\hline $\begin{array}{l}\text { curvilinear incised lines and } \\
\text { appliqued node }\end{array}$ & - & 1 & - & - & - & - & 1 \\
\hline \multicolumn{8}{|l|}{ Incised-Punctated } \\
\hline $\begin{array}{l}\text { cane punctated row at rim-body } \\
\text { juncture and vertical incised } \\
\text { lines on body }\end{array}$ & - & 1 & - & - & - & - & 1 \\
\hline $\begin{array}{l}\text { diagonal incised lines and } \\
\text { incised panels filled with tool } \\
\text { punctates }\end{array}$ & 1 & - & - & - & - & - & 1 \\
\hline $\begin{array}{l}\text { diagonal incised lines and } \\
\text { incised triangles filled with } \\
\text { tool punctates }\end{array}$ & - & 2 & - & - & - & - & 2 \\
\hline $\begin{array}{l}\text { incised triangles filled with } \\
\text { tool punctates and diagonal } \\
\text { opposed lines between } \\
\text { triangles }\end{array}$ & - & 1 & - & - & - & - & 1 \\
\hline Subtotal & 1 & 4 & - & - & - & - & 5 \\
\hline Lip Notched & - & - & 1 & - & - & - & 1 \\
\hline $\begin{array}{l}\text { Neck Banded } \\
\text { horizontal neck bands }\end{array}$ & 1 & 1 & - & - & 1 & - & 3 \\
\hline
\end{tabular}


Table 7. Decorative methods and elements represented in the utility ware sherds from the Womack site, cont.

\begin{tabular}{|c|c|c|c|c|c|c|c|}
\hline \multirow{2}{*}{$\begin{array}{l}\text { Decorative method } \\
\text { and elements }\end{array}$} & \multicolumn{2}{|c|}{ Grog } & \multicolumn{2}{|c|}{ Bone } & \multicolumn{2}{|c|}{ Shell } & \multirow[b]{2}{*}{$\mathrm{N}$} \\
\hline & rim & body & rim & body & rim & body & \\
\hline \multicolumn{8}{|l|}{ Pinched } \\
\hline curvilinear pinched rows & - & 1 & - & - & - & - & 1 \\
\hline \multicolumn{8}{|l|}{ Punctated } \\
\hline fingernail punctated rows & 2 & 10 & - & 1 & - & - & 13 \\
\hline fingernail punctated row below lip & - & - & - & - & 1 & - & 1 \\
\hline diagonal fingernail punctated row & 2 & - & 1 & 3 & - & - & 6 \\
\hline $\begin{array}{l}\text { diagonal fingernail punctated } \\
\text { row below lip }\end{array}$ & 1 & - & - & - & - & - & 1 \\
\hline opposed tool punctated rows & - & 1 & - & - & - & - & 1 \\
\hline tool punctated row & 4 & 10 & - & 3 & - & 2 & 19 \\
\hline tool punctated row below lip & - & - & 1 & - & - & - & 1 \\
\hline diagonal tool punctated row & 2 & - & - & - & 1 & - & 3 \\
\hline Subtotal & 9 & 23 & 1 & 5 & 5 & 2 & 45 \\
\hline Totals & 24 & 96 & 5 & 16 & 10 & 48 & 199 \\
\hline
\end{tabular}

The few brushed, brushed-incised, and brushed-punctated sherds in the assemblage are likely from utility wares made and used at the same time as the shell-tempered brushed vessels (see below), likely during a Late or Historic Caddo occupation at the Womack site. These utility ware sherds may be from Bullard Brushed vessels made by Caddo potters in the upper Sabine and upper Cypress stream basins.

The many grog- and bone-tempered incised rim and body sherds (n-78) in the Womack site assemblage are probably primarily from Canton Incised vessels, except for the bowl rims with horizontal incised lines (see Table 7). These latter sherds are probably from Davis Incised or Dunkin Incised vessels. The other incised decorative elements represented include cross-hatched lines (see Suhm and Jelks 1962:Plate 12c), diagonal opposed lines (see Suhm and Jelks 1962:Plate 12f-g), horizontal and diagonal opposed lines, horizontal and vertical lines, and horizontal and cross-hatched lines (Figure 7). It is also possible that some of these incised body sherds are from Emory Punctated-Incised vessels, as they are described as having incising that "consists of straight to slightly curved lines extending from below the rim to the base or to about the middle of the body" (Story et al. 1967:137).

The few sherds with incised-punctated decorative elements are only from vessels tempered with grog (see Table 7). In most cases, these sherds also appear to be from Canton Incised vessels with repeated triangular incised zones (from sets of diagonal opposed lines) filled with tool or cane punctates (Figure 8) or with diagonal incised panels filled with tool punctations.

The many fingernail impressed rim and body sherds in the Womack site utility wares (see Table 7) are from Monkstown Fingernail Impressed jars (see Suhm and Jelks 1962:Plate 55). The vessels decorated with either rows of square to triangular tool punctates may be from an as yet undefined utility ware type made by ancestral Caddo potters in the upper part of the East Texas Red River basin. 


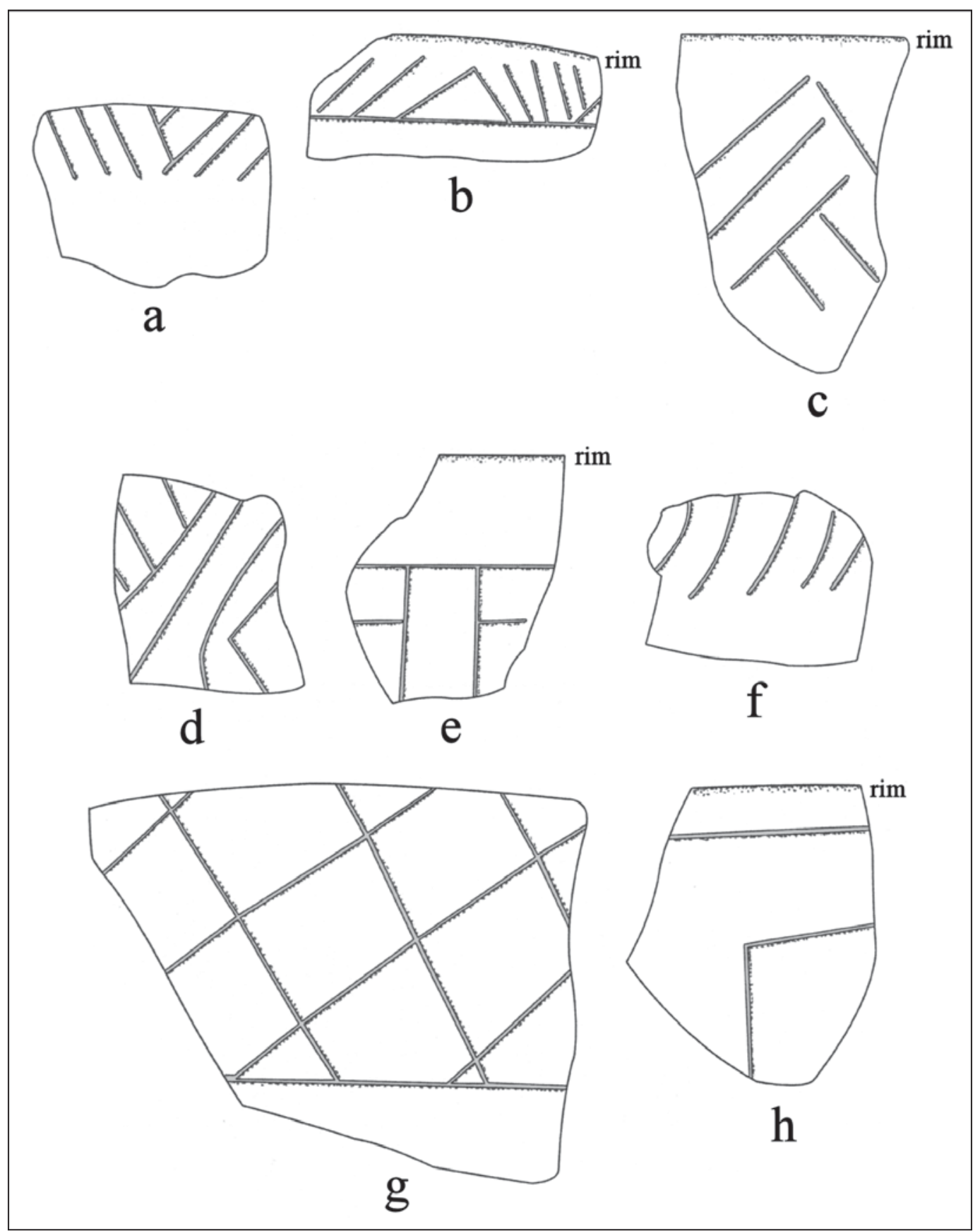

Figure 7. Decorative elements on grog- and bone-tempered incised rim and body sherds from the Womack site.

The grog- and bone-tempered appliqued and appliqued-punctated sherds are from Moore Noded and McKinney Plain vessels; the Moore Noded rim sherd is covered with small appliqued nodes, and these would have covered the entire body of a vessel (see Webb 1959:120 and Figures 67j, 75d, and 122a-b). The few grog- and bone-tempered neck banded sherds $(n=2)$ have horizontal rows of neck bands on the rim of utility ware jars. These sherds are from non-shell-tempered varieties of Nash Neck Banded. According to Krieger (2000:141), about 57 percent of the neck banded sherd/vessel batches in the Sanders site (41LR2) he analyzed had grog, sand/tuff, or bone temper; the remaining 43 percent had a fine shell temper. The one bone-tempered lip notched rim sherd (see Table 7) is from a non-red-slipped variant of Sanders Plain (see 


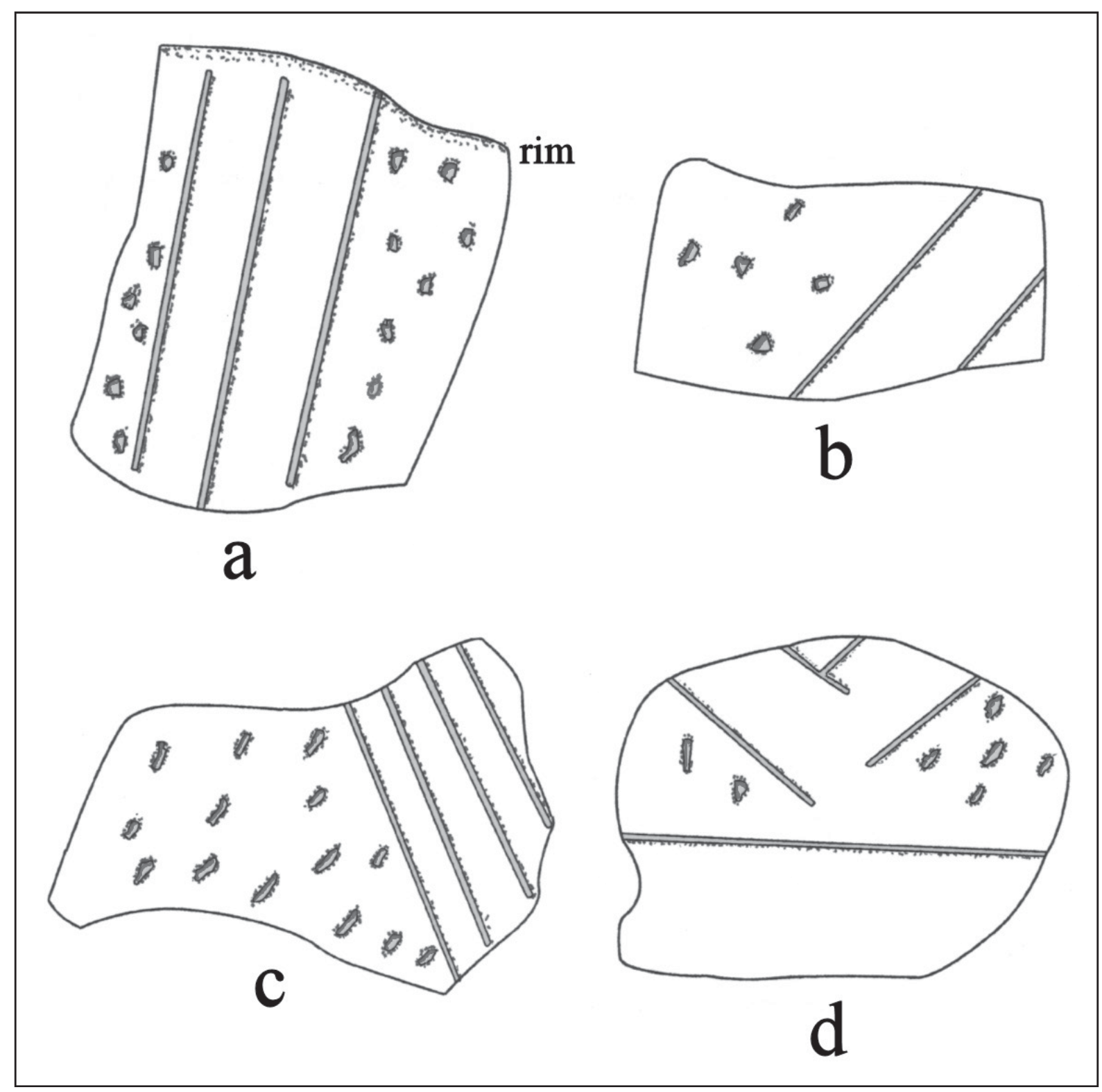

Figure 8. Decorative elements on grog-tempered incised-punctated rim and body sherds from the Womack site.

Suhm and Jelks 1962:139). The pinched body sherd has curvilinear pinched ridges, and may be from a Monkstown Fingernail Impressed jar.

The decorated shell-tempered utility ware rim and body sherds ( $\mathrm{n}=58$ sherds) include appliqued, appliqued-punctated, brushed, incised, neck banded, and punctated elements (see Table 7). They are part of the assemblage of ceramic wares associated with the late 17th to early 18th century occupation of the site by an ancestral Caddo group. The appliqued and appliqued-punctated sherds are most likely from McKinney Plain jars (see Suhm and Jelks 1962:Plate 49j, and the one shell-tempered neck banded rim is from a Nash Neck Banded vessel. The incised and punctated sherds have simple geometric incised lines or rows of fingernail or tool punctations from both Emory Punctated-Incised (Story et al. 1967:137) and McKinney Plain vessels. The shell-tempered brushed sherds at the Womack site resemble the same utility ware of unidentified type identified at the Gilbert site by Story et al. (1967:142 and Figure 58c-h). 


\section{Fine Ware Sherds}

The fine ware sherds from the Womack site include sherds from vessels that have engraved decorations that were executed when the vessel was leather-hard or already fired. Also included in the fine wares are many red-slipped sherds, as these primarily are from bowls, bottles, and carinated bowls, typical fine ware vessel forms, rather than from utility ware jars, and trailed sherds; the trailed sherd is included because the design element suggests it is from a Keno Trailed vessel with a fine ware shape.

Fine ware sherds - including sherds from vessels decorated with engraved, red-slipped, and trailed elements-comprise a substantial 43.8 percent of the decorated sherd assemblage at the Womack site. About 76 percent of the fine ware sherds are from engraved vessels; another 23.2 percent are from red-slipped vessels, and 0.6 percent are from vessels with trailed lines (Table 8). Engraved sherds from vessels with a red-slipped surface account for 3.8 percent of the grog-tempered sherds and 20.0 percent of the bone-tempered sherds.

Table 8. Decorative methods and elements represented in the fine ware sherds from the Womack site.

\begin{tabular}{|c|c|c|c|c|c|c|c|}
\hline \multirow{2}{*}{$\begin{array}{l}\text { Decorative method } \\
\text { and elements }\end{array}$} & \multicolumn{2}{|c|}{ Grog } & \multicolumn{2}{|c|}{ Bone } & \multicolumn{2}{|c|}{ Shell } & \multirow[b]{2}{*}{$\mathrm{N}$} \\
\hline & rim & body & rim & body & rim & body & \\
\hline \multicolumn{8}{|l|}{ Engraved } \\
\hline diagonal lines & - & 2 & - & - & - & - & 2 \\
\hline diagonal hatched zone & 1 & - & - & - & - & - & 1 \\
\hline diagonal hatched triangles & 1 & - & - & - & - & - & 1 \\
\hline $\begin{array}{l}\text { excised zone and pendant } \\
\text { triangle; int./ext. red- } \\
\text { slipped }\end{array}$ & - & - & - & 1 & - & - & 1 \\
\hline $\begin{array}{l}\text { hatched zone and negative } \\
\text { oval; int./ext. red-slipped }\end{array}$ & - & 1 & - & - & - & - & 1 \\
\hline $\begin{array}{l}\text { hatched and cross-hatched } \\
\text { triangles }\end{array}$ & - & 1 & - & - & - & - & 1 \\
\hline $\begin{array}{l}\text { hatched triangle; int./ext. } \\
\text { red-slipped }\end{array}$ & - & 1 & - & 1 & - & - & 2 \\
\hline horizontal-diagonal lines & 2 & 2 & - & - & - & - & 4 \\
\hline $\begin{array}{l}\text { horizontal and vertical lines } \\
\text { and cross-hatched semi- } \\
\text { circle }\end{array}$ & - & 1 & - & - & - & - & 1 \\
\hline opposed lines & - & 1 & - & - & - & - & 1 \\
\hline opposed curvilinear lines & - & 1 & - & - & - & - & 1 \\
\hline parallel lines & - & 1 & - & - & - & - & 1 \\
\hline straight line & - & 2 & - & 1 & - & - & 3 \\
\hline $\begin{array}{l}\text { straight line; int./ext. red- } \\
\text { slipped }\end{array}$ & - & 2 & - & - & - & - & 2 \\
\hline Hudson Engraved & - & - & - & 1 & - & 1 & 2 \\
\hline Patton Engraved & - & 1 & - & - & - & - & 1 \\
\hline
\end{tabular}


Table 8. Decorative methods and elements represented in the fine ware sherds from the Womack site, cont.

\begin{tabular}{|c|c|c|c|c|c|c|c|}
\hline \multirow{2}{*}{$\begin{array}{l}\text { Decorative method } \\
\text { and elements }\end{array}$} & \multicolumn{2}{|c|}{ Grog } & \multicolumn{2}{|c|}{ Bone } & \multicolumn{2}{|c|}{ Shell } & \multirow[b]{2}{*}{$\mathrm{N}$} \\
\hline & rim & body & rim & body & rim & body & \\
\hline Simms Engraved & - & - & - & - & 1 & - & 1 \\
\hline Taylor Engraved & 1 & - & - & - & - & - & 1 \\
\hline Womack Engraved & 21 & 64 & 1 & 5 & - & - & 91 \\
\hline Subtotal & 26 & 80 & 1 & 9 & 1 & 1 & 118 \\
\hline \multicolumn{8}{|l|}{ Red-Slipped } \\
\hline ext. red-slipped & - & 6 & - & 2 & - & 1 & 9 \\
\hline int./ext. red-slipped & $3 *$ & 15 & 1 & 3 & - & 5 & 27 \\
\hline Subtotal & 3 & 21 & 1 & 5 & - & 6 & 36 \\
\hline \multicolumn{8}{|l|}{ Trailed } \\
\hline parallel trailed & - & 1 & - & - & - & - & 1 \\
\hline Totals & 29 & 102 & 2 & 14 & 1 & 7 & 155 \\
\hline
\end{tabular}

*includes one with a scalloped lip

Several engraved rim and body sherds from grog- and bone-tempered vessels are likely from Sanders Engraved vessels (see Suhm and Jelks 1962:Plate 69). They have diagonal lines, hatched triangle elements pendant from the rim (Figure 9a), hatched diagonal zones (Figure 9b), hatched and cross-hatched triangles, horizontal and diagonal engraved lines, as well as opposed engraved lines (see Table 8).

Although they are not common (i.e., only 4.2 percent of the fine wares), there are a few engraved fine ware sherds from vessels that were likely not made locally. They include Hudson Engraved (Figure 10bc), Patton Engraved (Figure 10e), Simms Engraved (Figure 10a), and Taylor Engraved (Figure 10d); the Hudson Engraved sherds are from bottles, while the others are from bowls or carinated bowls. These sherds are primarily from vessels that may have been trade wares obtained from post-A.D. 1600 McCurtain phase Caddo groups living downstream on the Red River, near the confluence of the Kiamichi and Red rivers (in the case of the Hudson Engraved and Simms Engraved sherds), or groups in the upper Big Cypress and upper Sabine River basins (in the case of the Taylor Engraved sherd). The Patton Engraved sherd is from a vessel that would have been made after ca. A.D. 1650 among Hasinai Caddo groups in the upper Neches and Angelina River basins in East Texas, well south of the Womack site. The Patton Engraved sherd is either from a var. Freeman or var. Fair globular bowl (see Perttula et al. 2015a:Figure 5c-d). Harris et al. (1965:301) also noted sherds from likely non-locally made shell-tempered Natchitoches Engraved, Simms Engraved, Hudson Engraved, and Avery Engraved vessels in their sherd assemblage; these comprised about 1.7 percent of the decorated sherds in the assemblage.

Womack Engraved is the principal fine ware in the assemblage, comprising about 77 percent of all the engraved sherds (see Table 8). These sherds are from grog- and bone-tempered vessels; none of the sherds are from shell-tempered Womack Engraved vessels, which is different from the sample of Womack Engraved sherds discussed by Harris et al. (1965:301).

Womack Engraved was defined by Duffield and Jelks (1961:36-39 and Figures 9 and 10) on the basis of vessels and sherds from sites in the Red and Sabine River basins in East Texas that date from the late 


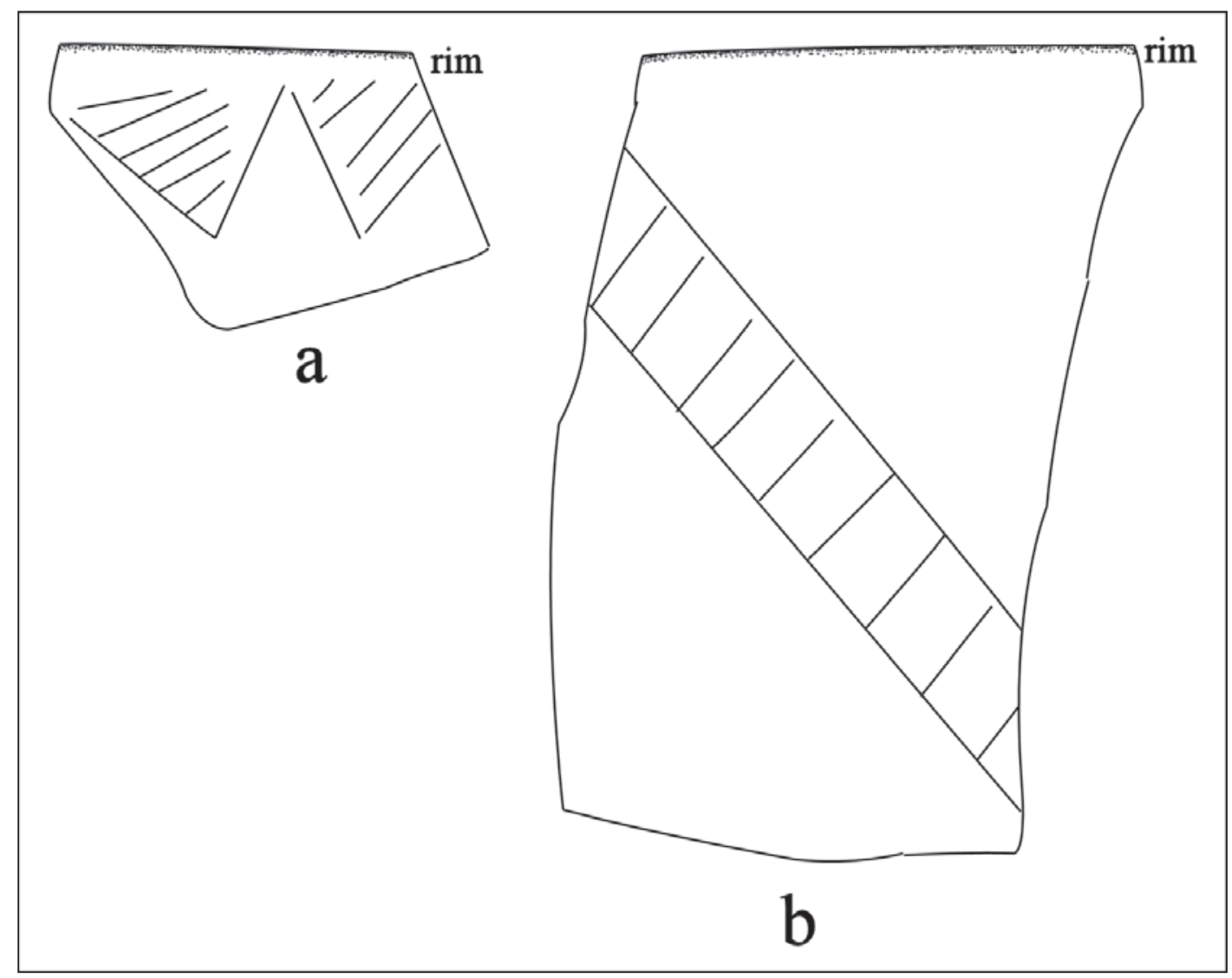

Figure 9. Possible decorative elements on Middle Caddo fine ware sherds from the Womack site.

17th century to the mid-18th century. Subsequent archaeological investigations have also identified Womack Engraved vessels and sherds from Late Caddo Titus phase sites in the Little Cypress Creek basin. Womack Engraved vessels tend to be carinated bowls with inverted rims.

Previous analyses by Duffield and Jelks (1961:36-40), Harris et al. (1965:299-303), and Story et al. (1967:114-124) have identified four Womack Engraved designs, motifs A-D (Story et al. 1967:Figure 49a-d). Motif A has opposed cross-hatched triangles; Motif B a negative meandering scroll with a ticked line running along the center of the scroll; Motif $\mathrm{C}$ consists of parallel and arcing curvilinear lines with or without tick marks; and Motif D has a negative scroll with ticked lines and cross-hatched pendant triangles running down the center of the scroll (see Story et al. 1967:Figure 49). In the sample of Womack Engraved sherds from the UT investigations at the Womack site, only Motifs A, B, and D are present in the assemblage (Table 9). Of those sherds $(n=49)$ where the Womack Engraved motif can be definitely identified, more than 63 sherds are from Motif A vessels (Figure 11; see also Figure 3a); another 29 percent are from Motif B vessels (Figure 12); and 8 percent are from Motif D vessels (Figure 13; see also Figure 3b). There are another 37 sherds too small to be assigned to other than Motif B or D vessels, and five other Womack Engraved body sherds where no motif assignment can be made. In the Harris et al. (1965:301) sample of Womack Engraved sherds $(n=744)$, Motif $B$ is by far the most common in this sample, representing more than 81 percent of the Womack Engraved sherds; Motif C sherds, absent in the UT sherd assemblage, comprise about 10 percent, and Motif A another 8 percent. As mentioned above, another difference between the UT assemblage of Womack Engraved sherds and the Harris et al. (1965) sample is that almost 9 percent of the Womack Engraved sherds in the Harris et al. (1965:301) are from shell-tempered vessels, while none of the UT sample of Womack Engraved sherds are from shell-tempered vessels. 


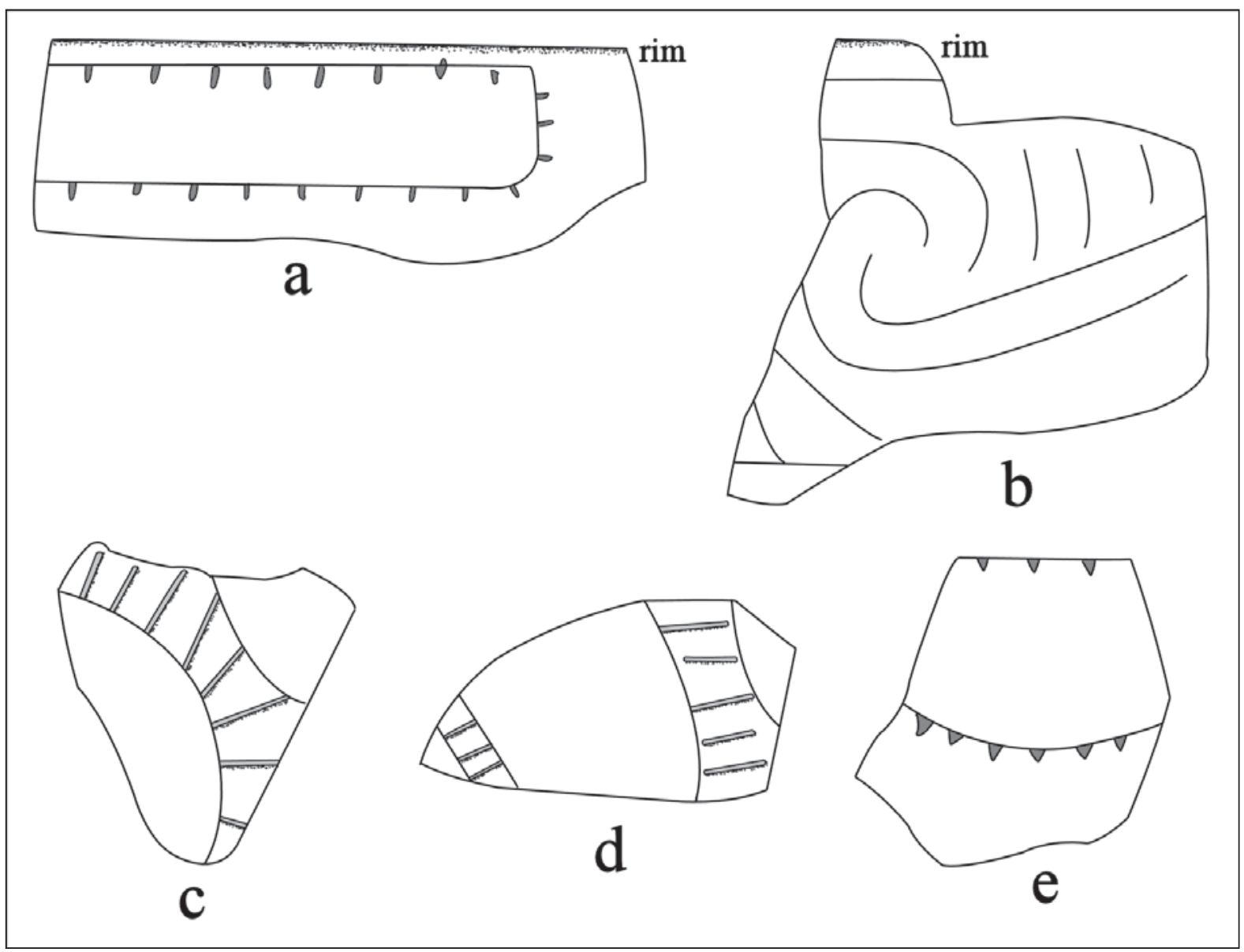

Figure 10. Decorative elements on Hudson Engraved, Patton Engraved, Simms Engraved, and Taylor Engraved sherds from the Womack site.

Table 9. Decorative elements and motifs on Womack Engraved sherds from the Womack site.

\begin{tabular}{|c|c|c|c|c|c|}
\hline \multirow[b]{2}{*}{ Motif } & \multicolumn{2}{|c|}{ Grog-tempered } & \multicolumn{2}{|c|}{ Bone-tempered } & \multirow[b]{2}{*}{$\mathrm{N}$} \\
\hline & rim & body & rim & body & \\
\hline A & 8 & 23 & - & - & 31 \\
\hline B & 3 & 11 & - & - & 14 \\
\hline $\mathrm{D}$ & - & 3 & 1 & - & 4 \\
\hline $\mathrm{B}$ or $\mathrm{D}$ & 10 & 23 & - & 4 & 37 \\
\hline Undetermined & - & 4 & - & 1 & 5 \\
\hline Totals & 21 & 64 & 1 & 5 & 91 \\
\hline
\end{tabular}




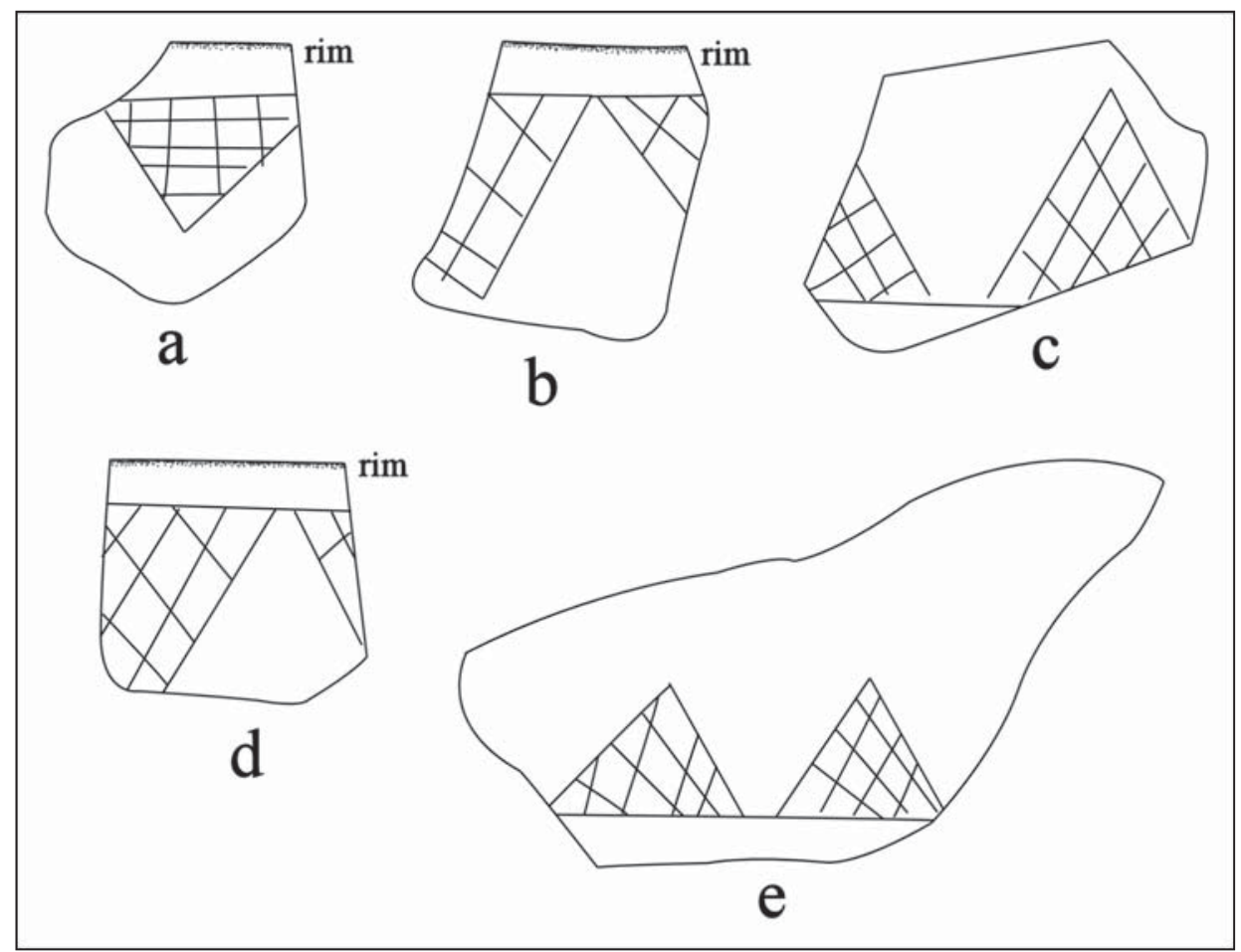

Figure 11. Womack Engraved Motif A rim and body sherds.

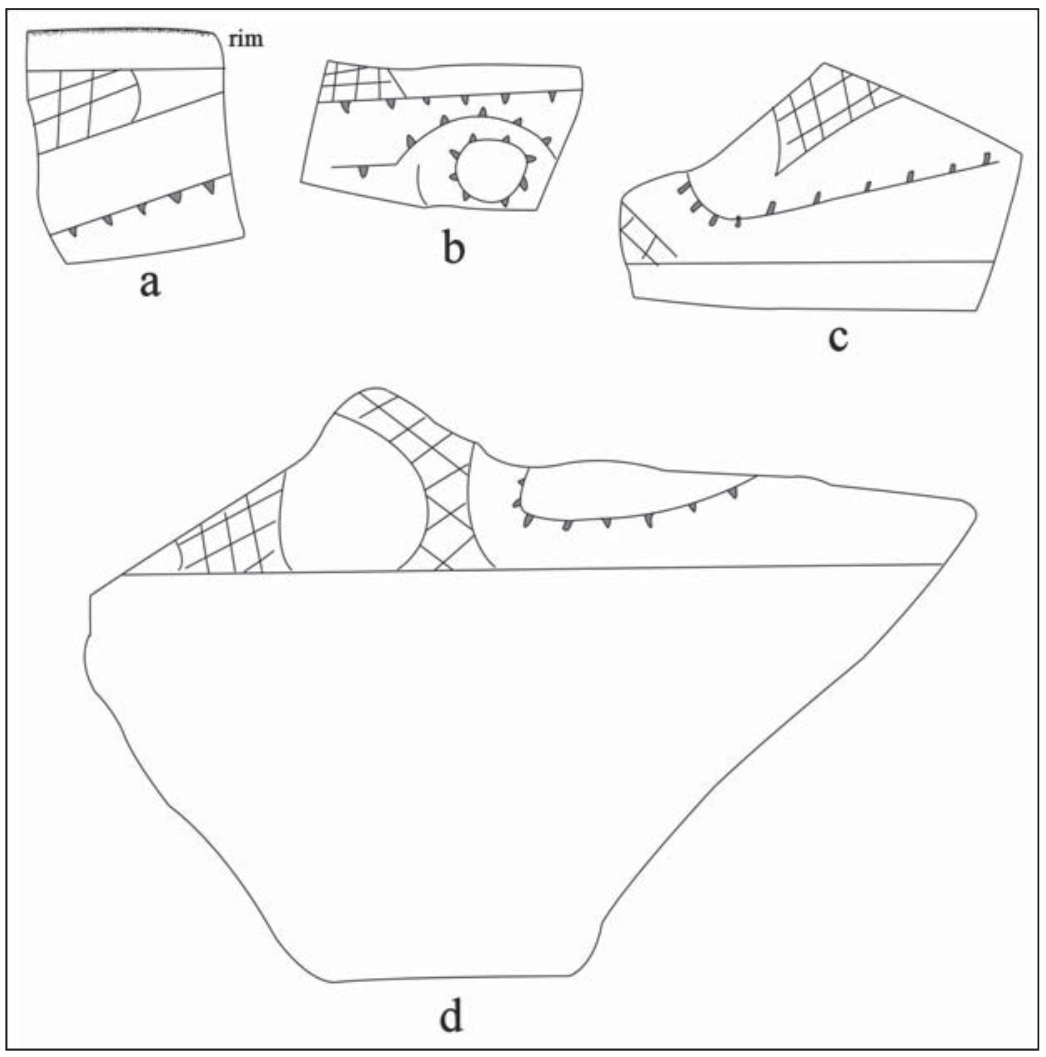

Figure 12. Womack Engraved Motif B rim and body sherds. 


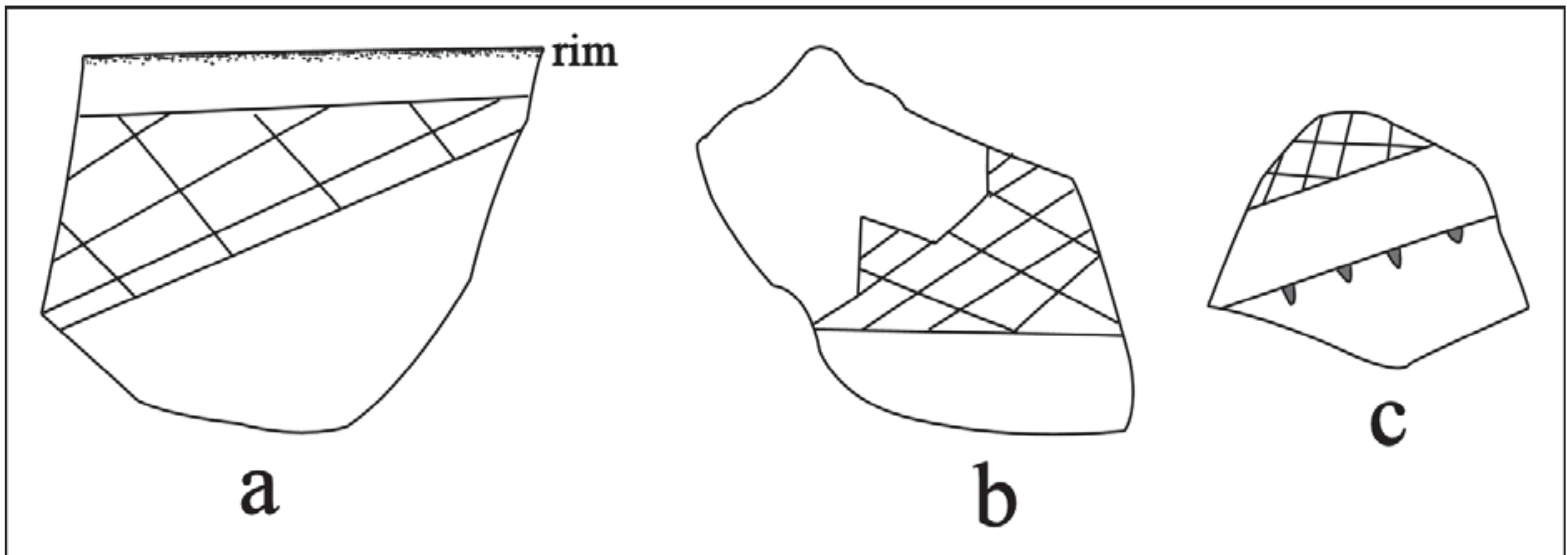

Figure 13. Womack Engraved Motif D rim and body sherds.

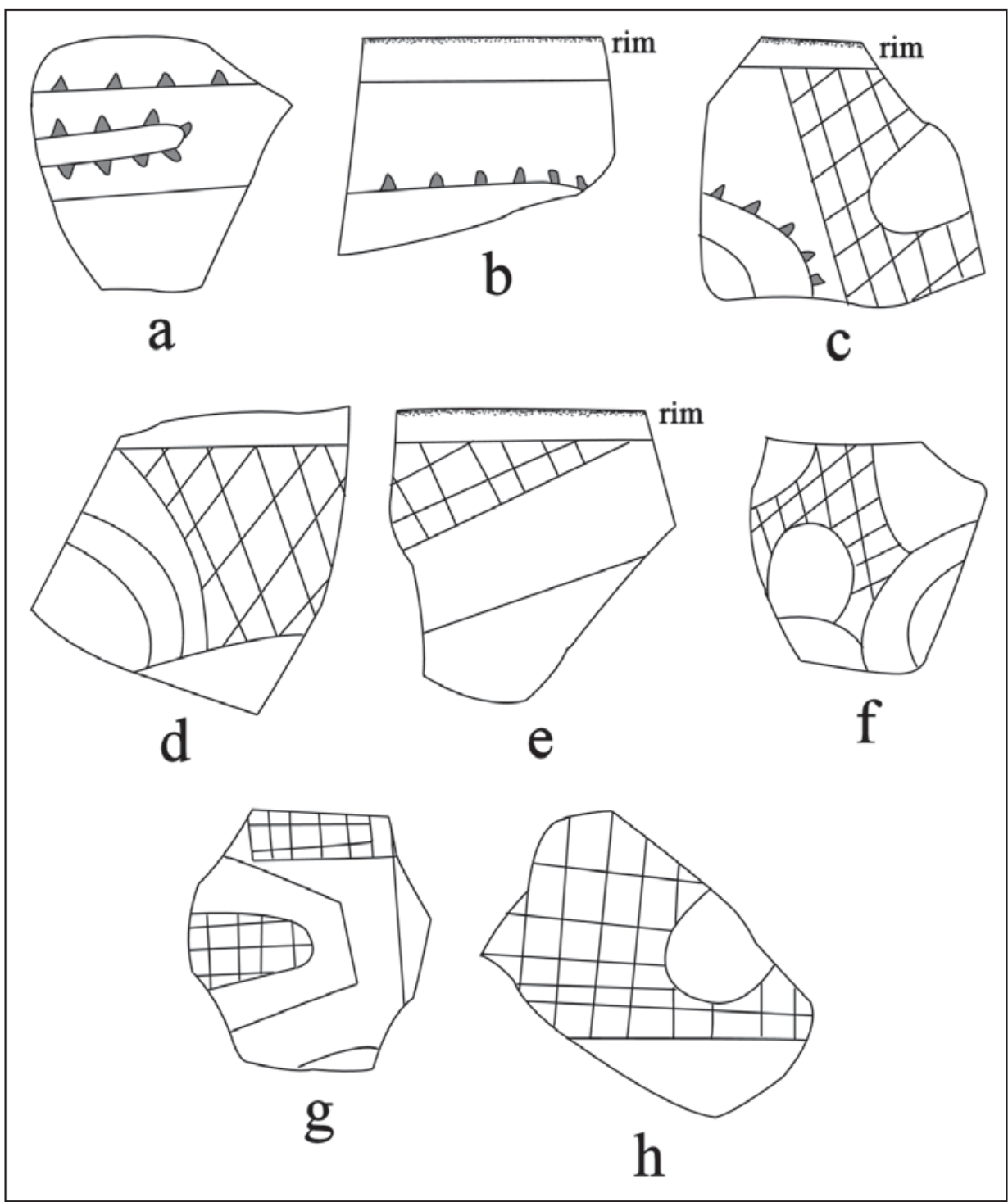

Figure 14. Womack Engraved Motif B or D rim and body sherds. 
The relatively abundant grog- and bone-tempered red slipped sherds in the fine wares (see Table 8) are from Sanders Plain vessels, as redefined by Brown (1996:401-403 and Figures 2-191, 2-34g, 2-37a-1, 2-38d, 2-39d, k, n-q, and 2-42b). Sanders Plain is a grog-tempered, slipped, and otherwise undecorated type found widely across the Caddo area, including the middle reaches of the Red River and the upper Sabine River basin. Vessel forms include bowls, carinated bowls, and narrow and wide-mouthed bottles. Pre-A.D. 1400 ceramic assemblages where red-slipped sherds are relatively abundant are well represented at sites such as Jamestown (41SM54), Sam Kaufman (41RR16), A. C. Mackin (41LR31), and Sanders (41LR2) on the Sabine and Red rivers, respectively.

The shell-tempered red-slipped sherds are likely from Late and/or Historic Caddo period Clement Redware bowls or carinated bowls (see Flynn 1976). Later ceramic assemblages ( i.e., dating after A.D. 1400) with red-slipped sherds are found most notably in shell-tempered wares in McCurtain phase sites on the middle reaches of the Red River (see Perttula 2015b:Figure 3) and the ca. A.D. 1680-1740 component at the Sanders site (Perttula et al. 2015b).

The one grog-tempered trailed body sherd (see Table 5) may be from a Keno Trailed bowl. In East Texas, sherds with trailed decorative elements are found in low percentages in ceramic assemblages in only a few parts of East Texas, principally in sites on the Red River (Perttula 2015:Figure 4). These sites generally date between ca. A.D. 1400 (or later) and A.D. 1730. The highest proportion of trailed sherds in ceramic assemblages are found in various Texarkana phase village and mound areas at the Hatchel site (41BW3) on the Red River (Perttula 2014), well downstream from the Womack site.

\section{Ceramic Pipes}

There is one complete and plain elbow pipe in the artifact assemblage. It is bone-tempered, and has a collar at the stem (Figure 15). The pipe is $40.0 \mathrm{~mm}$ in height and $46.9 \mathrm{~mm}$ in length, with an exterior stem diameter of $23.0 \mathrm{~mm}$, and an exterior bowl diameter of $26.8 \mathrm{~mm}$. The bowl height is $24.9 \mathrm{~mm}$.

There are several plain $(n=2)$ or engraved $(n=3)$ grog-tempered elbow pipe bowl sherds from the site, as well as a grog-tempered elbow pipe stem; bowl heights range from 28.1-44.0 $\mathrm{mm}$. The engraved elbow pipe bowls have horizontal engraved lines with hatched pendant triangles (one or two rows of hatched pendant triangles), and another pipe bowl has two rows of cross-hatched pendant triangles (Figure 16). The majority of the elbow pipes recovered by Harris et al. (1965:303 and Figure 6f) from Womack are decorated with the same small cross-hatched engraved triangles, while three pipes are decorated with rows of punctations like Historic Allen phase elbow pipes in the upper Neches River basin (Perttula 2011:215 and Figures 6-23 and 6-24d; see also Jackson 1933:75 and Plate 28).

There are also long-stemmed Red River style pipes in the Womack site assemblage. The first is a sherd with a complete bowl and a broken pipe stem (Figure 17). The bowl height is $28.1 \mathrm{~mm}$, and it has an exterior bowl orifice diameter of $26.0 \mathrm{~mm}$. The stem has an exterior diameter of $13.6 \mathrm{~mm}$, and an interior stem diameter opening of $7.0 \mathrm{~mm}$. This may be part of a Red River pipe, Haley variety (Hoffman 1967:10). The second is a grog-tempered pipe stem with an exterior diameter of $10.0 \mathrm{~mm}$ and an interior stem hole diameter of only $2.8 \mathrm{~mm}$; this conforms to the Graves Chapel variety of Red River pipe (Hoffman 1967:9).

\section{Bone Tools and Ornaments}

There is one tubular and polished bone bead in the collection. It is $6.0 \mathrm{~mm}$ in diameter and $17.0 \mathrm{~mm}$ in length. There are also three deer ulna awls. 


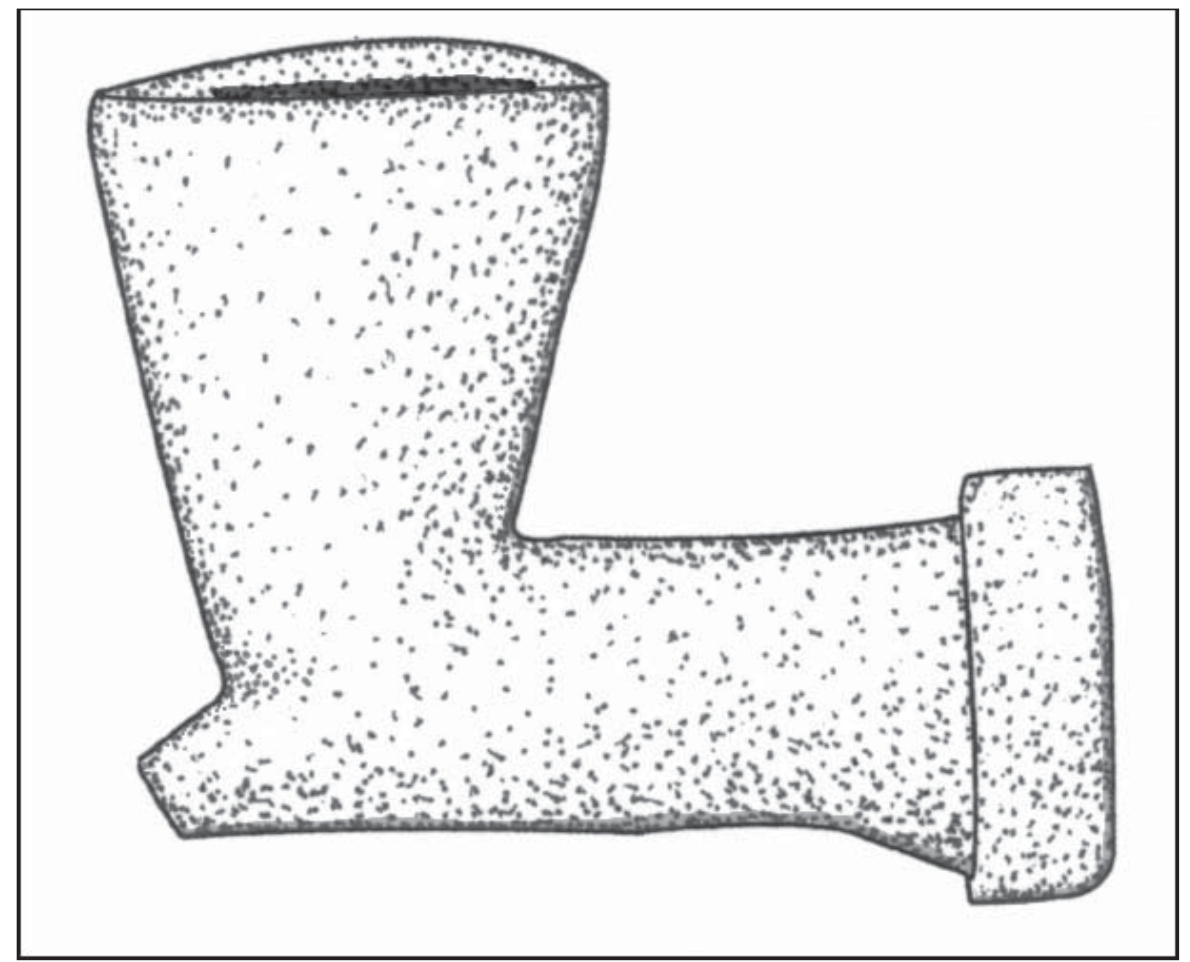

Figure 15. Complete elbow pipe from the Womack site.

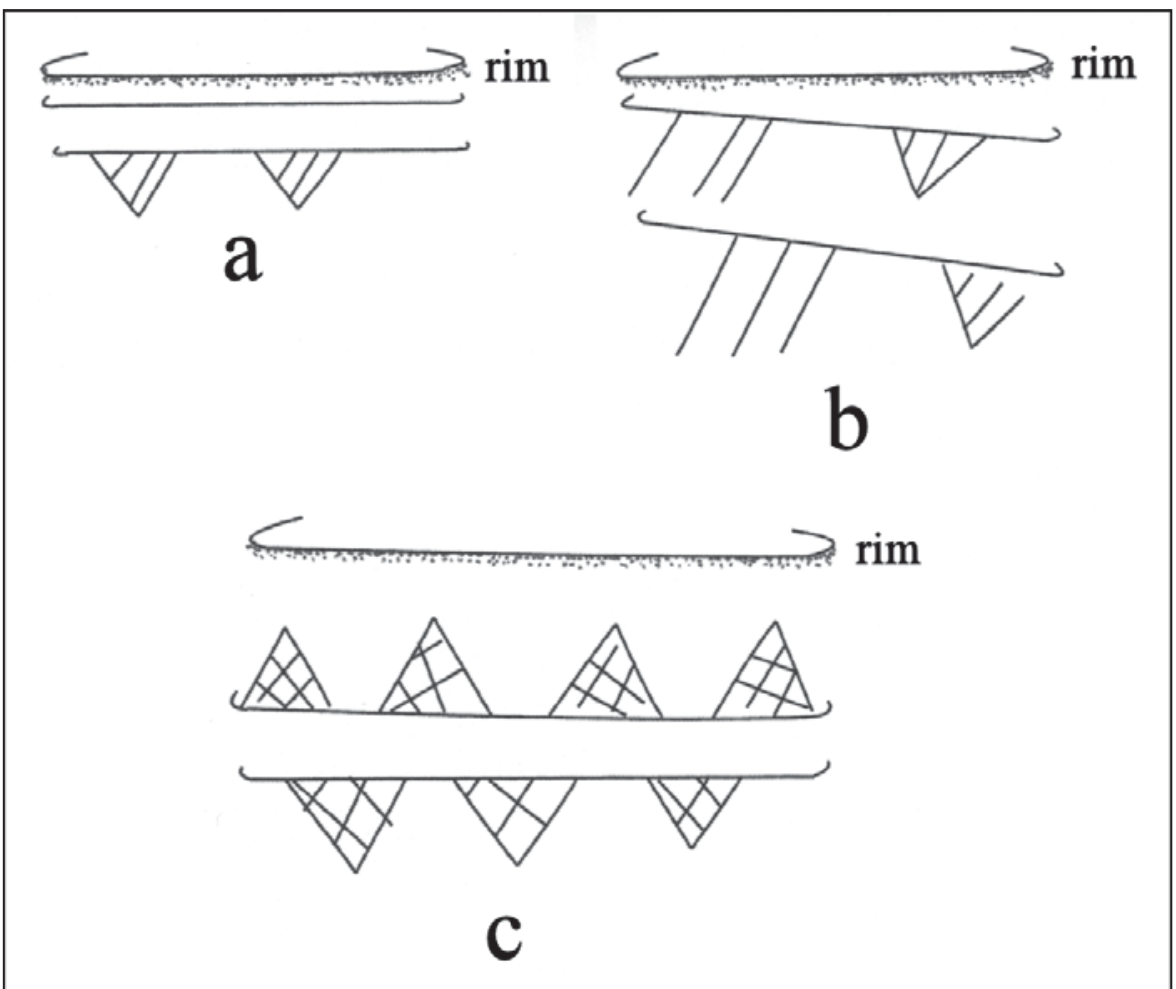

Figure 16. Engraved decorative elements on engraved elbow pipe bowl sherds. 


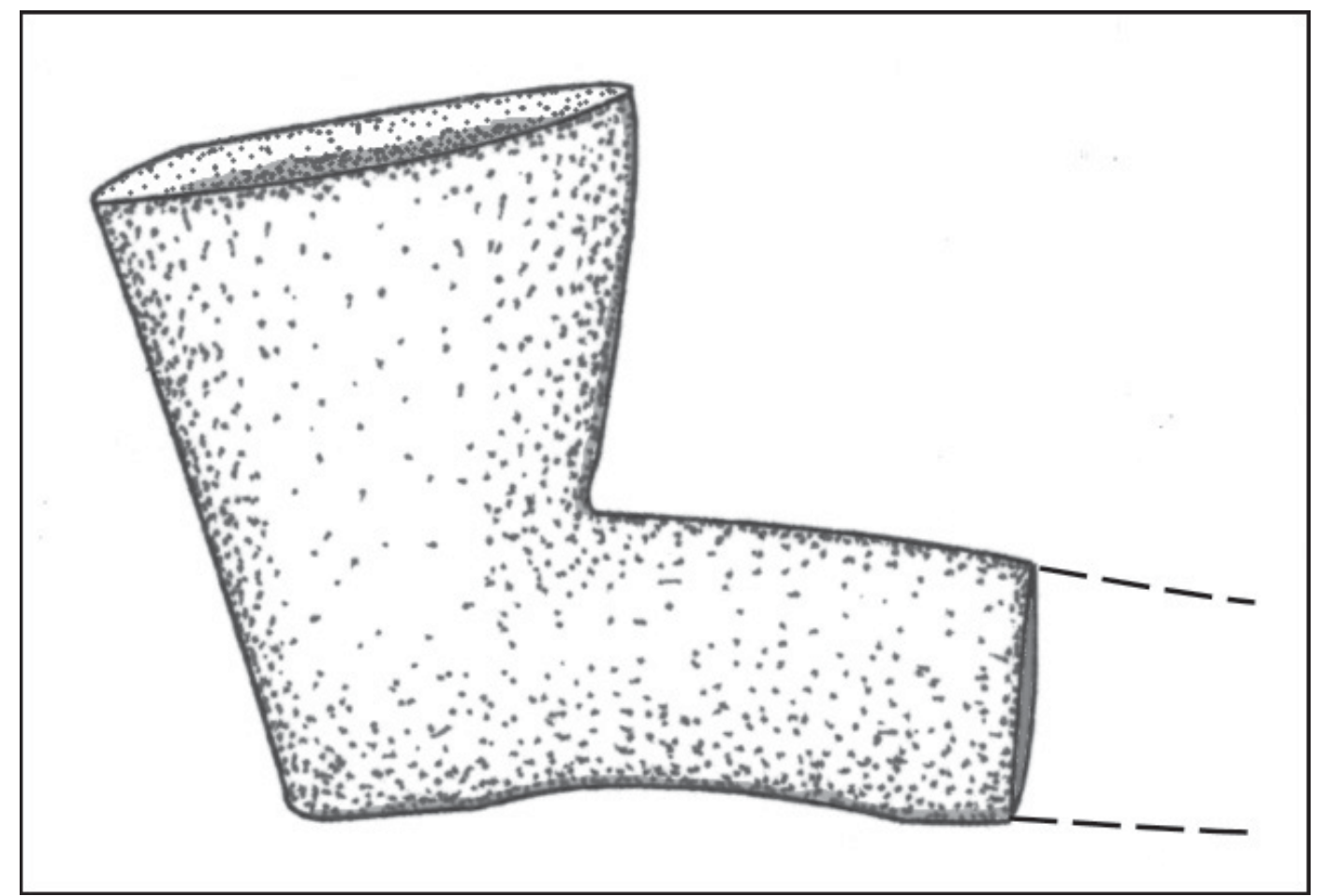

Figure 17. Long-stemmed Red River style pipe from the Womack site.

\section{Shell Tools and Ornaments}

Shell ornaments include small to large conch shell beads $(n=13)$. These beads have diameters that range from 2.8-14.0 mm, and almost 80 percent of the beads are small, with diameters ranging from 2.8-4.3 mm. There are also nine fossil shell beads, all about 13.0-13.5 $\mathrm{mm}$ in diameter.

The one mussel shell tool in the assemblage is a perforated mussel shell hoe.

\section{European Trade Goods}

A wide array of European trade goods, including native-made artifacts manufactured from European materials, have been recovered at the Womack site during the UT investigations. Most common are glass beads, gun parts, brass kettle fragments, and brass cone-shaped tinklers.

\section{Awl}

A small iron awl is in the UT collection (Figure 18; see also Harris et al. 1965:Figure 21h). It is 82.0 $\mathrm{mm}$ in length and $5.7 \mathrm{~mm}$ in thickness.

\section{Bottle Glass}

There is one olive green wine bottle glass sherd in the artifact assemblage from the Womack site. 


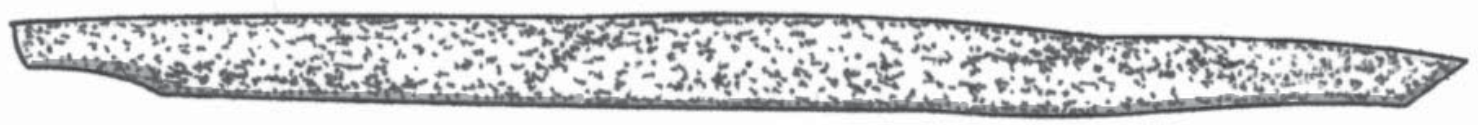

Figure 18. Iron awl from the Womack site.

\section{Brass Bead}

One European trade good in the Womack site collection is a tubular rolled brass bead made from a piece of kettle. The bead is $67.9 \mathrm{~mm}$ in length, $10.0 \mathrm{~mm}$ in diameter, and $0.6 \mathrm{~mm}$ in thickness (i.e., likely 25 gauge, Harris et al. 1965:305 and Figure 7c).

\section{Brass Button}

The one brass button is a plain compound button with a $5.1 \mathrm{~mm}$ long attachment loop; the brass wire loop itself is missing. The button is $18.2 \mathrm{~mm}$ in diameter.

\section{Catlinite}

Pearce and Jackson (1931:3) reported that a Catlinite pipe stem sherd from an elbow pipe was found on the surface of the Womack site during the UT investigations. However, this pipe sherd was not identified in the TARL collections. Harris et al. (1965:Figure 3k) recovered a Catlinite pipe from the site, and Todd (2010:139-142 and Figures 1 and 2) discussed both Catlinite pipe sherds from Womack. These pipes in use at the Womack site are evidence of the Caddo's participation in calumet ceremonialism during the early $18^{\text {th }}$ century (e.g., Rodning 2014).

\section{Faience}

A single plain body sherd from a tin-glazed faience vessel, possibly a plate, is in the UT collections from the Womack site. The sherd has a thick and evenly-applied glaze, and the paste is orangish-brown in color.

\section{Glass Beads}

There is a sample of 117 glass beads in the Womack site assemblage, and they are characterized according to the Harris et al. (1965) and Harris and Harris (1967) bead classification system (Table 10). Most of the beads are large (> $6 \mathrm{~mm}$ in diameter) opaque white beads of several shapes (56 percent), and there are also large translucent olive-shaped blue beads (5.1 percent). Another 13.7 percent are medium-sized (4-6 $\mathrm{mm}$ in diameter) beads of white ( 6.8 percent) and blue ( 6.8 percent). The remainder of the beads are small in size $(<4 \mathrm{~mm}$ in diameter, 24.8 percent $)$, and these are white $(n=8)$, blue $(n=17)$, clear $(n=1)$, red $(n=1)$, and Cornaline d'Aleppo beads $(\mathrm{n}=2)$ with a red outer core and a green inner core. Overall, approximately 70 percent of the glass beads are white, 26 percent are blue, 2.6 percent are red, and 0.9 percent are clear or colorless. 
Table 10. Glass beads from the Womack site.

\begin{tabular}{|c|c|c|}
\hline Harris No. & $\mathrm{N}$ & Bead Description \\
\hline 1 & 1 & large, olive-shaped, opaque, white \\
\hline 2 & 58 & large, elongated olive-shaped, opaque, white \\
\hline 3 & 7 & large, round, opaque, white \\
\hline 6 & 7 & medium, olive-shaped, opaque, white \\
\hline 11 & 7 & medium, barrel-shaped, opaque, peacock blue \\
\hline 13 & 6 & large, olive-shaped, translucent, dark blue \\
\hline 14 & 1 & medium, olive-shaped, translucent, dark blue \\
\hline 44 & 6 & small, donut-shaped, opaque, white \\
\hline 45 & 2 & small, donut-shaped, opaque, white \\
\hline 46 & 5 & small, donut-shaped, opaque, blue \\
\hline 47 & 11 & small, donut-shaped, opaque, blue \\
\hline 48 & 1 & small, donut-shaped, translucent, blue \\
\hline 49 & 1 & small, donut-shaped, clear glass \\
\hline 51 & 2 & $\begin{array}{l}\text { small, donut-shaped, opaque, red outer layer-green inner layer; Cornaline } \\
\text { d'Aleppo beads }\end{array}$ \\
\hline 137 & 1 & medium, tubular or barrel-shaped, opaque, white \\
\hline UID (176?) & 1 & small, round or donut-shaped, translucent, red \\
\hline Totals & 117 & \\
\hline
\end{tabular}

Following the bead chronological periods defined by Harris and Harris (1967:156-158), these beads from the Womack site would date to the earliest period of the appearance of glass beads in East Texas Caddo sites, from ca. A.D. 1700-1740. Harris and Harris (1967:156) suggest that these beads have their source in "French settlements in Louisiana."

\section{Gunflints}

The collection has one European-made spall gunflint (see Harris et al. 1965:341 and Figure 17k-m). It is made from an unknown chert.

\section{Gun Parts}

Among the gun parts in the UT collection from the Womack site are two plain brass butt plate fragments, a brass thumb plate escutcheon with horizontal engraved lines, a brass trigger guard with an engraved Chevrolet trademark-like decorative element (Figure 19; see also Harris et al. 1965:Figure 12m), and a cast brass 
side plate with an engraved floral design (Figure 20; see also Harris et al. 1965:Figure 13c). There is one iron flintlock cock (see Harris et al. 1965:Figure 11a-a') of the gooseneck style (see Hamilton 1968:15 and Plate 22), and a possible plain finial section to a trigger guard (Figure 21; see also Harris et al. 1965:Figure 12e-f)

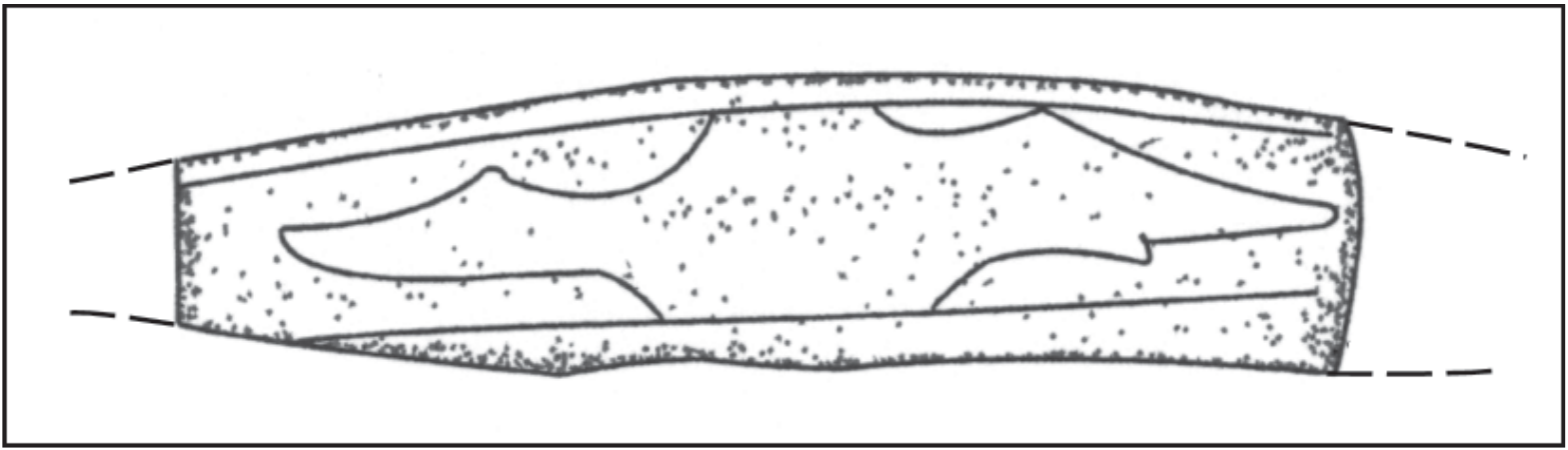

Figure 19. Brass trigger guard from the Womack site.

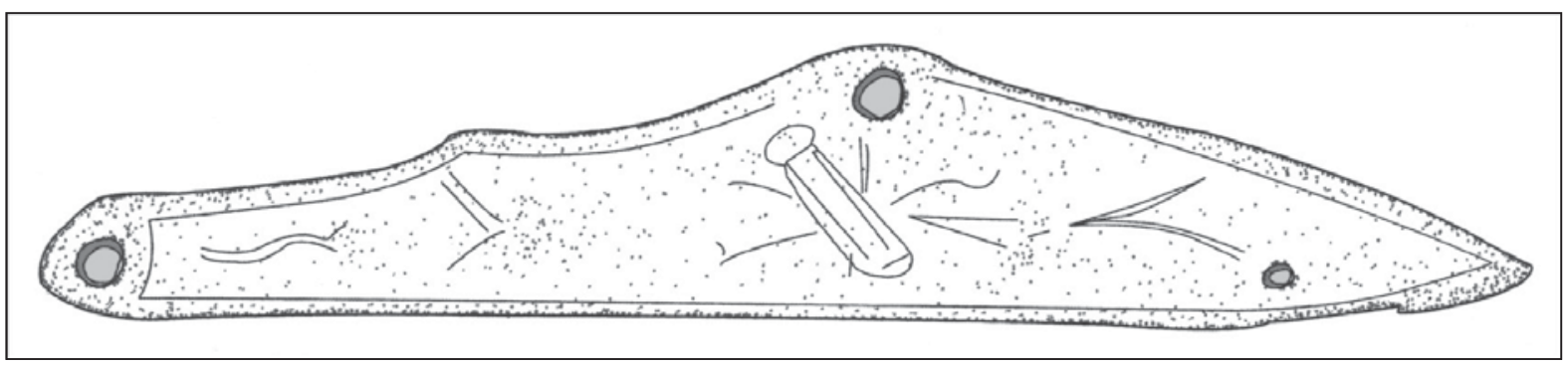

Figure 20. Brass side plate from the Womack site.

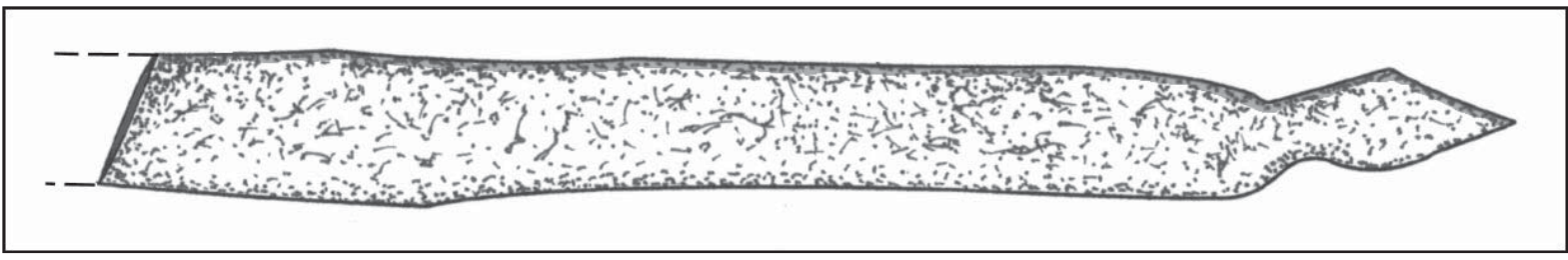

Figure 21. Possible finial section of a trigger guard from the Womack site.

There is also one iron ramrod guide fragment in the collection. These were attached to the forestock of a musket and would hold the ramrod in place (Harris et al. 1965:334-335).

\section{Kettle Fragments}

There are a number of brass kettle fragments in the UT Womack site collection. This includes three rim fragments (3.1-3.2 mm in thickness) with rolled rims, 17 kettle side or bottom fragments - one with a punched hole - that range from 1.0-2.0 mm in thickness, and a brass kettle bail lug with two rivets (Figure 22). The rivers would have held the kettle bail lugs onto the kettle. 


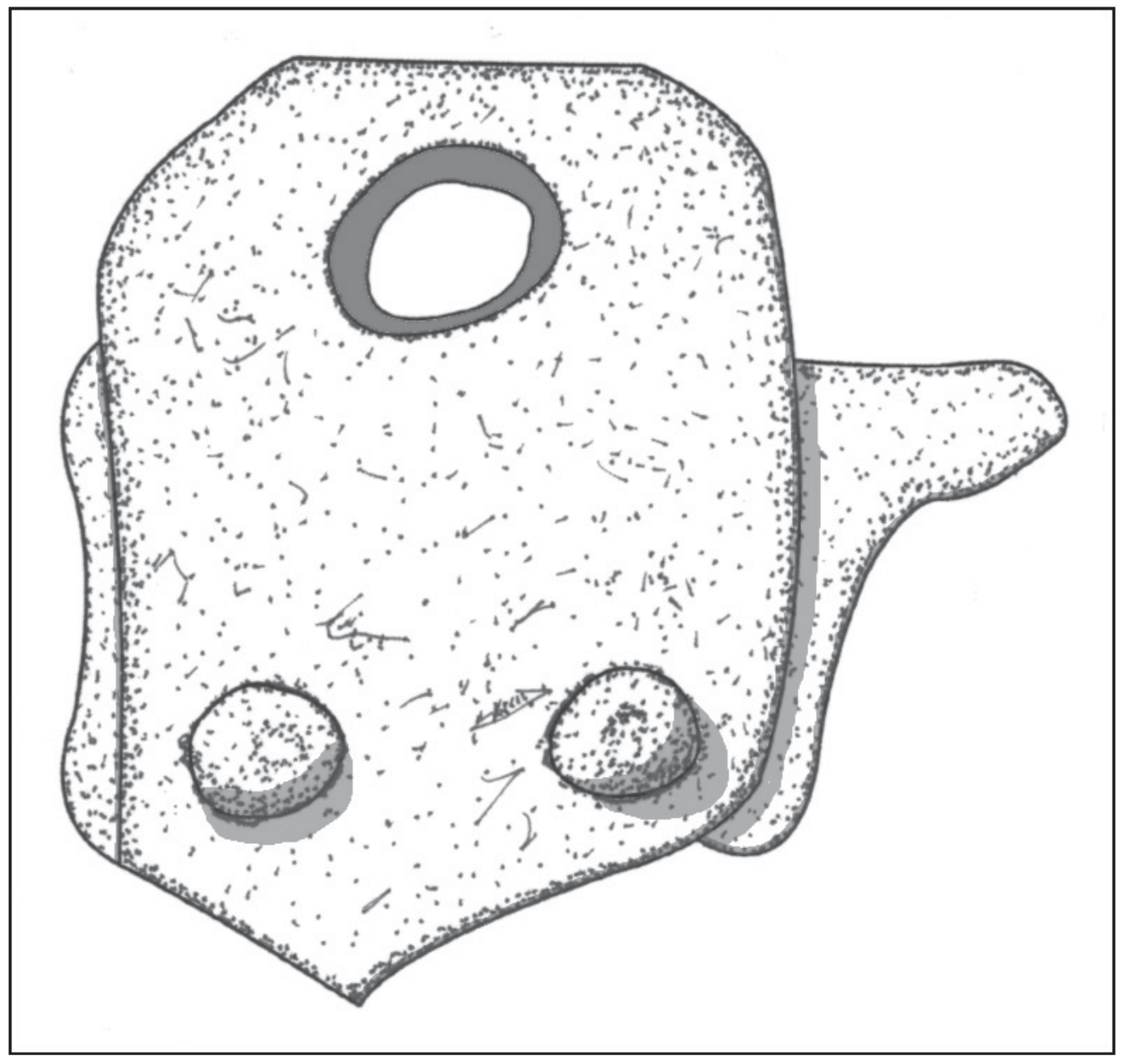

Figure 22. Brass kettle bail lug from the Womack site.

\section{Knives}

There are two hand-forged iron knive fragments, probably case knives, in the UT collection from the Womack site. The first has a short but wide tang (Figure 23a), perhaps part of a butcher knive, while the other is a Type 2 case knive fragment (Figure 23b) with a long and narrow rod-like tang relative to the blade size (Harris et al. 1965:Figure 20e) at the butt of the blade; the tang would have been inserted into the handle of the knive. This knive fragment was recovered in UT excavations in one of the midden deposits (Pearce and Jackson 1931:4).

\section{Lead Balls}

There are seven spherical lead balls/bullets in the UT Womack site collection. These range from 13.0-14.6 mm in diameter (see also Harris et al. 1965:Figure 19a-b). These lead balls would have been used in a French flintlock musket, and their size is comparable to a French infantry ball (Hamilton 1979:Table 16). 


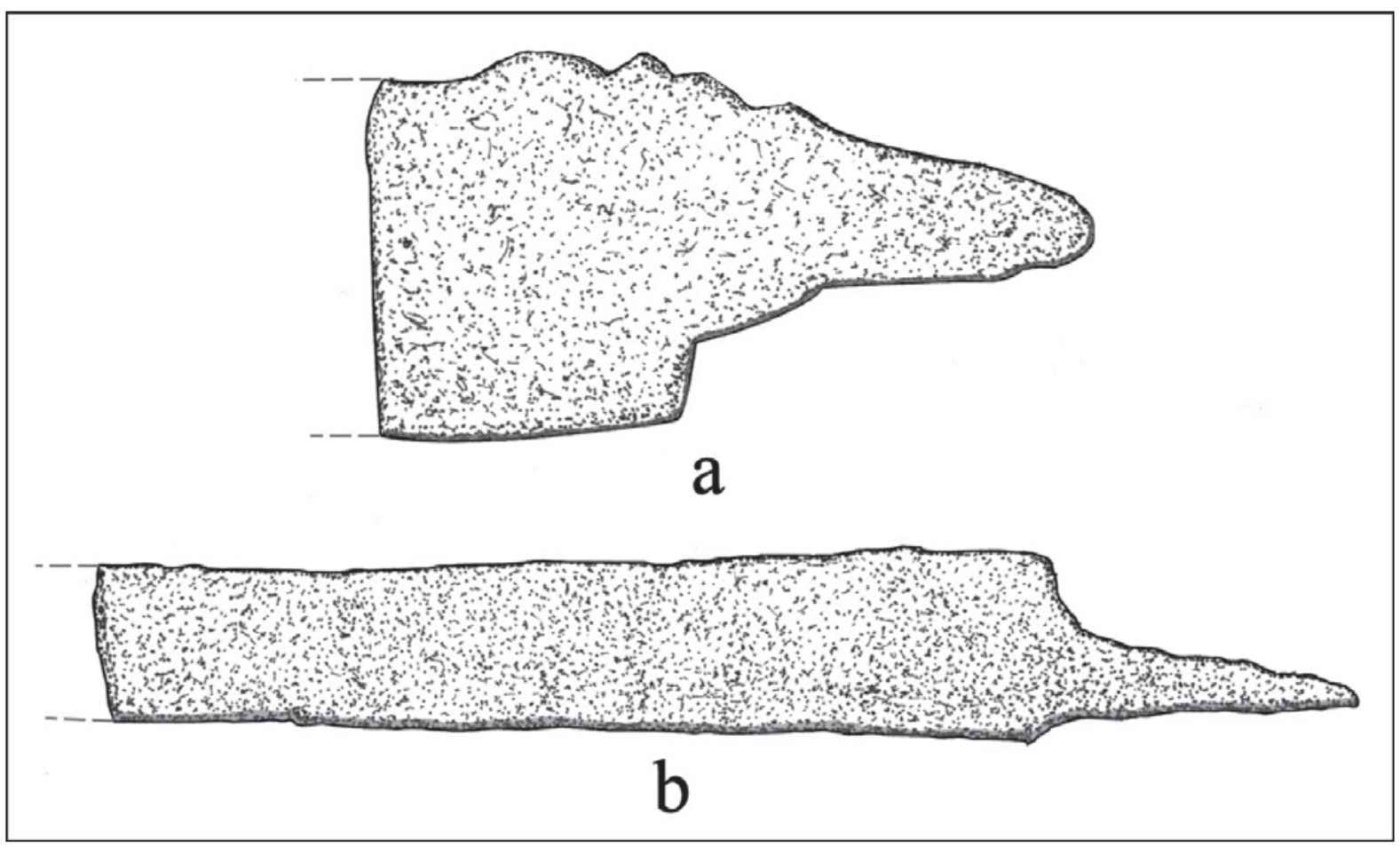

Figure 23. Case knive fragments from the Womack site.

\section{Projectile Point}

A single iron projectile point is in the artifact assemblage. It has a triangular blade and a long parallel stem (19 $\mathrm{mm}$ in length and $8 \mathrm{~mm}$ in width) and flat base (Figure 24). It is $44 \mathrm{~mm}$ in length, $19 \mathrm{~mm}$ in width, and between 3.4-4.0 $\mathrm{mm}$ in thickness.

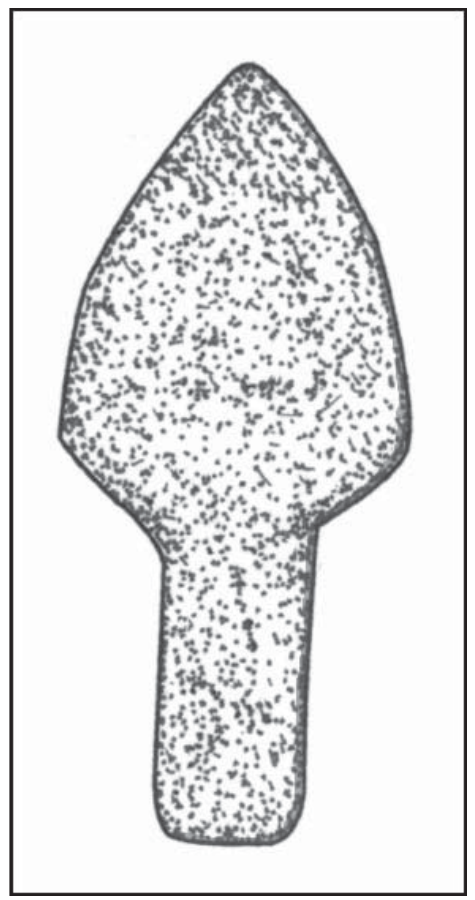

Figure 24. Iron projectile point from the Womack site. 
There is also a rolled brass point from the Womack site. It is $44.0 \mathrm{~mm}$ in length and the point is $4 \mathrm{~mm}$ thick.

\section{Tinklers}

Harris (1946; see also Harris et al. 1965:Figure 17g-i) described some of the brass cone-shaped tinklers recovered from the Womack site. The UT collection has seven such brass tinklers, from 23-65 mm in length and 10-22 $\mathrm{mm}$ in width. These tinklers would have been attached to an article of clothing through holes at the top and bottom of the cone.

\section{RADIOCARBON DATES}

Two samples of deer bone recovered during UT excavations in midden deposits at the Womack site have been submitted for radiocarbon dating by Direct AMS. The first sample (D-AMS 007077) is a fragment of mandible, while the second sample is a fragment of a deer vertebra (D-AMS 007078).

The first sample has a conventional radiocarbon age of $580 \pm 21$ years B.P. At 2 sigma, using OxCal v4.2.4, the deer remains in the midden have age ranges of A.D. 1308-1363 and A.D. 1386-1413 (Figure 25a). The median calibrated age is A.D. 1345, indicating some use of midden deposits during the Middle Caddo period (i.e., Sanders phase). The deer vertebra has a conventional radiocarbon age of $294 \pm 25$ years B.P. At 2 sigma, these remains have age ranges of A.D. 1512-1601 and A.D. 1616-1665 (Figure 25b). The median calibrated age is A.D. 1562. This calibrated date indicates that the midden deposits at the Womack site were being used during the Late Caddo period, perhaps as late as the mid-17th century A.D.

\section{SUMMARY AND CONCLUSIONS}

The Womack site is an ancestral Caddo settlement and cemetery on a Red River alluvial terrace in Lamar County, Texas. It is well known because of the many years of archaeological investigations carried out by members of the Dallas Archeological Society at the site and the article on those investigations published by Harris et al. (1965). Less well known are the University of Texas at Austin (UT) investigations at the Womack site in 1931. The main purpose of this article is to summarize the archaeological findings from the UT work at the site, as well as to provide analyses of the recovered artifacts, both aboriginal as well as European trade goods. A secondary purpose is to propose a Womack phase that pertains to the late 17thmid-18th century occupations and archaeological deposits at certain sites along the upper Red River such as Womack, Sanders (41LR2), Goss Farm (41FN12), and Harling (41FN1) in Lamar and Fannin counties, Texas, and the Gilbert (41RA13) and Pearson (41RA5) sites in the upper Sabine River basin.

Although the main occupation of the Womack site by aboriginal peoples occurred between ca. A.D. 1700-1730, the archaeological remains and recovered artifacts, as well as two radiocarbon dates on deer bone from midden deposits, indicate that the site was used in other periods. Based on projectile points, the first documented use of the site was during the Late Paleoindian period, followed by more substantial occupations during the Late Archaic and Woodland periods; the latter occupation is marked by numbers of Gary and Kent dart points on local quartzite raw materials, but no obvious habitation features or burials that might mark a more permanent occupation.

The next aboriginal occupation that can be recognized in the artifacts and features at the Womack site was by ancestral Caddo peoples during the ca. A.D. 1100-1300+ Sanders phase. The midden deposits present at the site likely began to accumulate during the latter part of this period, as suggested by one radiocarbon date with a median calibrated age of A.D. 1345, and at least one burial feature excavated by UT archaeologists was part of this occupation. The Caddo occupation at the site was probably year-round, although the 


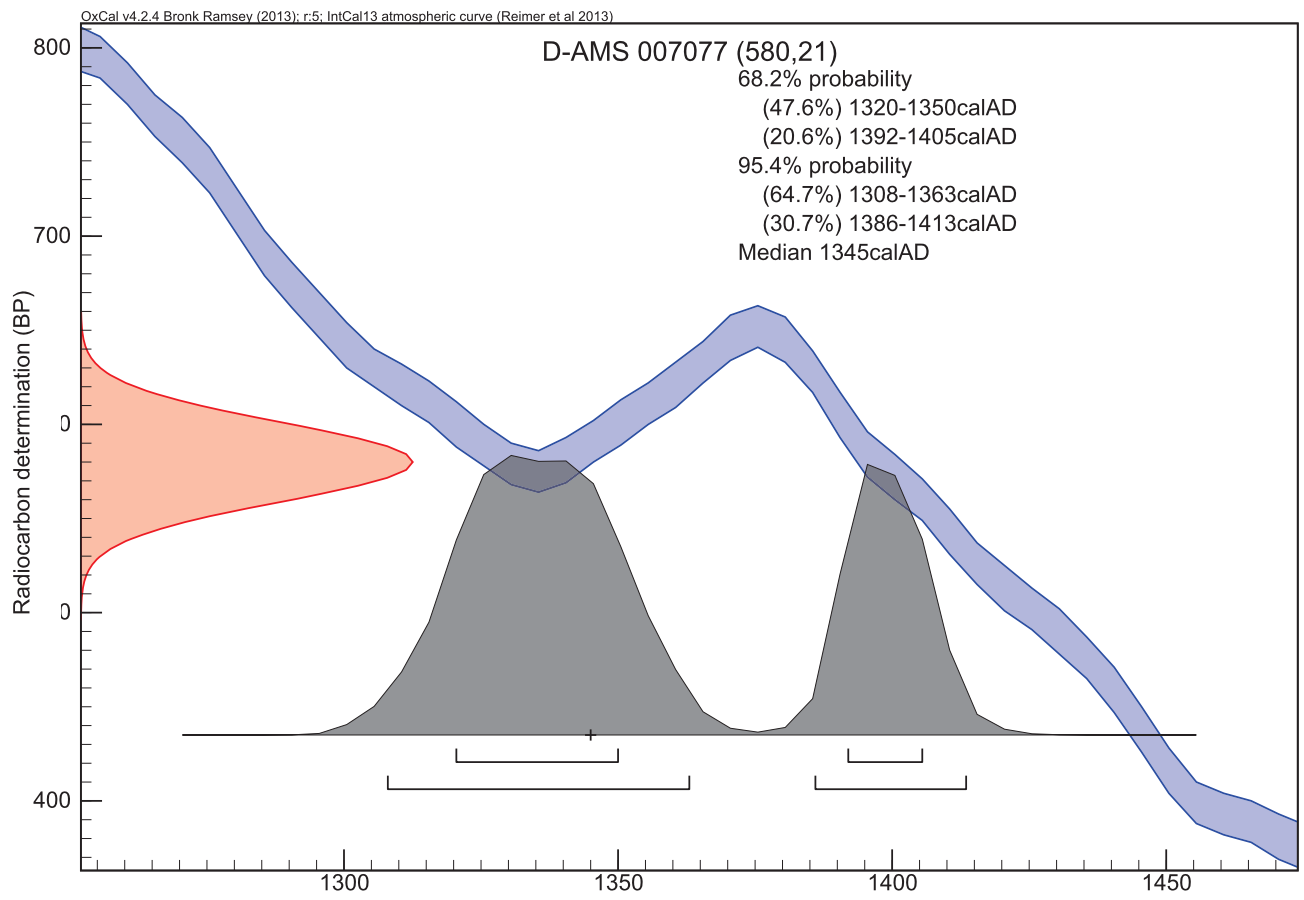

Calibrated date (calAD)

a

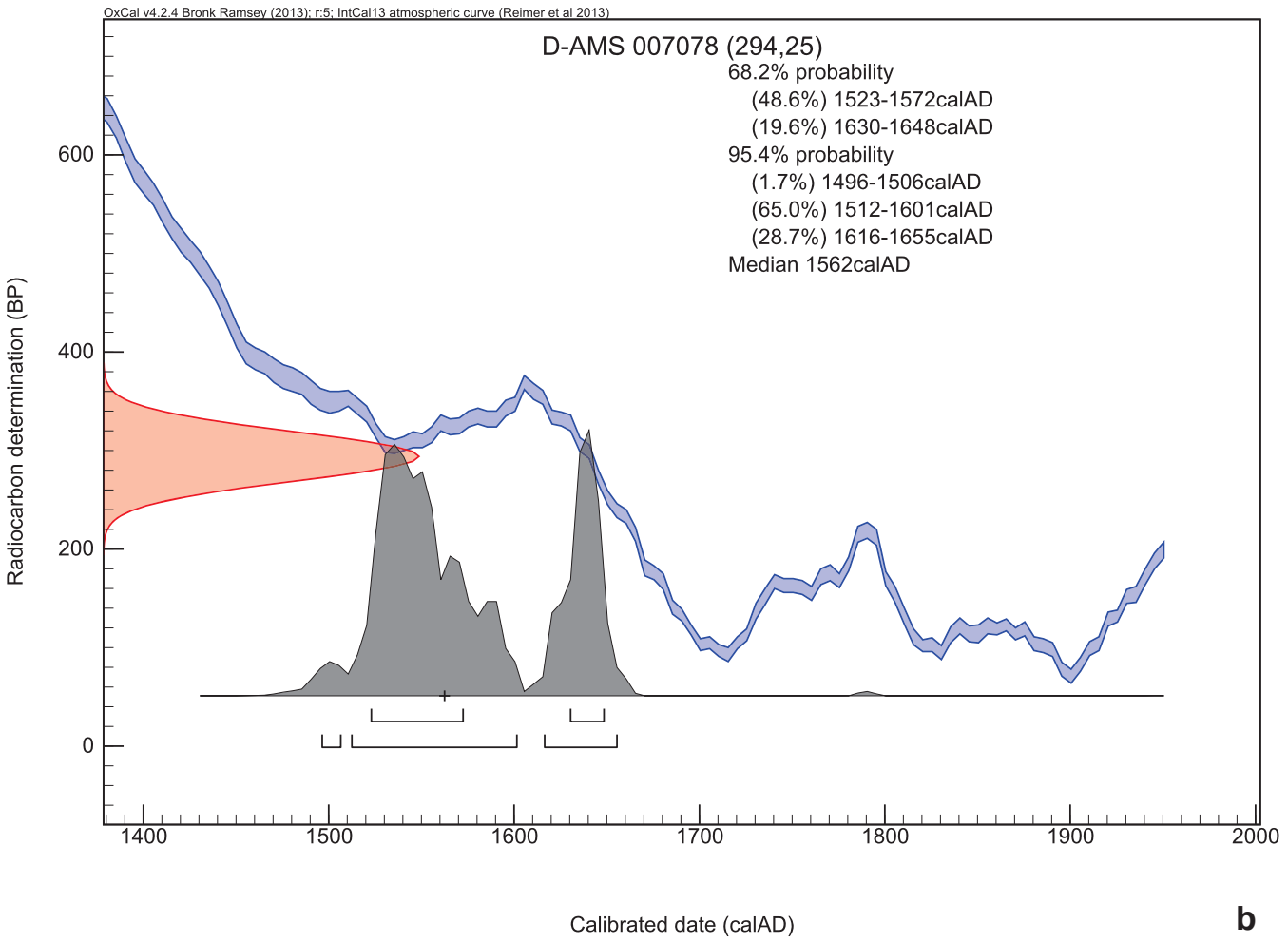

Figure 25. Results of radiocarbon dating of deer bones from midden deposits at the Womack site: a, D-AMS 007077; b, D-AMS 007078. 
size of the population that lived at the Womack site is not known. The material culture assemblage of this Caddo occupation included stemmed arrow points such as Bonham and Alba types, as well as sherds from grog- and bone-tempered plain (and plain ware vessels from a burial), utility, and fine ware vessels of the Sanders Engraved, Sanders Plain, Canton Incised (one vessel of this type was a funerary offering in one of the burials excavated by UT at the site), Monkstown Fingernail Impressed, Davis Incised, and Dunkin Incised vessels. There are also long-stemmed Red River pipe sherds in the assemblage.

\section{The Womack Phase}

Archaeological components of the Womack phase are found in two clusters, the first in a series of four sites on the upper Red River in the western part of the Post Oak Savannah in East Texas - principally at the Womack and Sanders sites - and the second cluster at the Gilbert (Jelks 1967) and Pearson (Duffield and Jelks 1961) sites in the upper Sabine River basin (Figure 26), also along the western edge of the Post Oak Savannah. These components appear to date from ca. A.D. 1690 to ca. A.D. 1750 (and probably later than that at the Pearson site), but it would not be surprising to eventually discover and document Womack phase

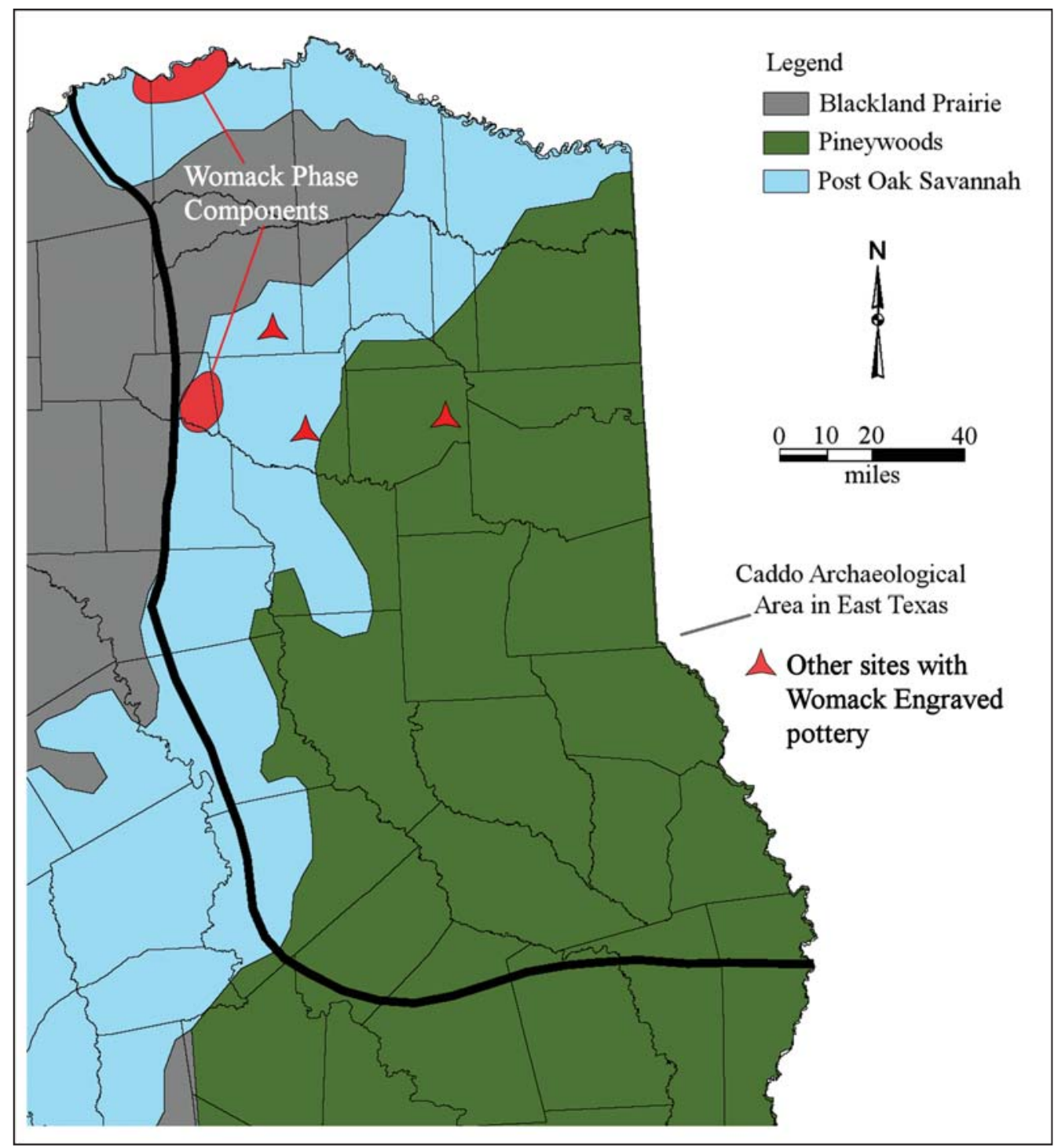

Figure 26. Distribution of Womack phase components in East Texas, and other East Texas sites with Womack Engraved pottery. 
sites in East Texas that date earlier than ca. A.D. 1690 to others that date from the late 18th century to the early 1800s. One of the radiocarbon dates from the midden at the Womack site has a 2 sigma age range of A.D. 1512-1665, with a median calibrated age of A.D. 1562, but it is unclear if this date has any relevance to establishing the absolute age of the Womack phase.

The key criteria in the material culture record for Womack phase components are a variety of European trade goods, likely obtained from French traders, and cf. Fresno triangular arrow points, an abundance of scraping tools, and beveled knives. The abundance of these hunting tools and scrapers at Womack phase sites strongly suggests that the inhabitants were heavily invested in the procurement and processing of hides (deer and bison) for the burgeoning fur trade, and the exchange of hides was what led to their adoption and acquisition of French guns, tools, and ornaments.

Also comprising diagnostic attributes of Womack phase components are the manufacture and use of engraved elbow pipes, and shell-tempered ceramics (both fine wares and utility wares), along with the continued making of grog- and bone-tempered plain wares, fine wares, and utility wares. Inverted rim Womack Engraved ceramic vessels are the principal fine ware in Womack phase sites, and Emory Punctated-Incised vessels are the principal utility ware. The stylistic character of the engraved motifs known to occur on Womack Engraved vessels, and the stylistic relationships between certain distinctive engraved motifs and inverted rim carinated bowls, suggest that a strong case can be made that the Womack phase groups and communities were ancestral Caddo groups and communities, and not Norteno (Wichita/Kichai) peoples.

Since the 1960s Womack Engraved has been viewed as a material culture trait diagnostic of the Norteno focus, and has been specifically linked with 18th century Norteno groups living on the southern Plains and along the western edges of East Texas. These groups are all considered to be non-southern Caddo groups but Wichita-Tawakoni or Kichai in cultural affiliation (Duffield and Jelks 1961:80; Harris et al. 1965:360; Jelks 1967:244). I have a different perspective on the stylistic development and cultural affiliation of the Womack Engraved ceramic type.

First, the relatively frequent occurrence of inverted rim engraved vessels from a number of late 17th century Caddo sites in the Sabine, Sulphur, and Little Cypress drainage basins in East Texas (see Cast et al. 2006; Perttula 2007:137-141, 2009; Perttula et al. 2012) provide evidence for protohistoric settlement in these areas by Caddo peoples. They also provide stylistic evidence for the development of early 18th century Womack Engraved vessels out of a late 17th century Titus phase stylistic tradition that included distinctive red-slipped Taylor Engraved and Ripley Engraved inverted rim vessels. Simms Engraved inverted rim vessels may also have played a role in the stylistic development of Womack Engraved ceramics on the upper Red River in the Caddo area.

Perttula (2007:141-142) stated the key stylistic and formal relationships between these Caddo ceramic types included the following:

a) development of inverted rim carinated bowls;

b) earlier use of red-slipping on this vessel form; red-slipping is a common decorative element in upper Sabine and upper Big Cypress Titus phase ceramic vessel assemblages;

c) later use of shell-tempering in this vessel form (as also seen in Simms Engraved vessels);

d) ticked engraved lines, either on scrolls or semi-circles; and

e) hooked arm scrolls, including the meandering scroll, as seen on Taylor Engraved vessels on the Red River and in East Texas Caddo sites. 
Later changes and the full expression of the stylistic character of Womack Engraved included adding cross-hatched border areas or scroll dividers (the earlier inverted rim forms have hatched triangular scroll dividers) and the development of large cross-hatched engraved triangles as a distinctive motif (Motif A of Womack Engraved). These occur either pendant from the vessel rim or pendant from the central engraved line running through the middle of the rim scroll.

These intimate stylistic relationships between Taylor Engraved and Womack Engraved inverted rim vessels dating from the period of ca. A.D. 1670-1730 that appears to have arisen out of a Titus phase ceramic tradition hopefully should dispel the notion that Womack Engraved is a Wichita-Tawakoni or Norteno ceramic type; admittedly, Womack Engraved does occur on Norteno sites at Spanish Fort and in late 18th century sites in the Brazos River basin (Bell et al. 1967; Stephenson 1970; Smith 1993). The occurrence of Womack Engraved vessels and their ancestral stylistic forms (i.e., Taylor Engraved inverted rim engraved carinated bowls, Simms Engraved inverted rim engraved carinated bowls, Womack Engraved, var. Gum Creek [Perttula and Nelson 2007:Figure 2f; Perttula et al. 2012:Figures 19, 40, 50, 229], and some red-slipped Ripley Engraved vessels) in burials on late Titus phase sites that generally lack any trade goods indicate that certain Caddo groups still lived in the Sulphur, Sabine, and Little Cypress Creek basins after much of the region had been abandoned around ca. A.D. 1670. These Caddo groups developed this distinctive vessel form and its constellation of stylistic elements and motifs, which reached their full stylistic maturation by the early 18th century at the Womack site on the Red River and by the middle to late 18th century at the Gilbert and Pearson sites in the upper Sabine River basin.

Womack Engraved vessels have been recovered from Fort Coffee phase sites in the Arkansas River basin of eastern Oklahoma (Rogers 2006:Table 2; Rohrbaugh 2012:Figures B.26-27); all those illustrated by Rohrbaugh (2012) have Motif A engraved decorations. Baugh (2009:Figure 1) considers Fort Coffee phase sites to represent a protohistoric Wichita group. Rogers (2006:24) indicates that the Womack Engraved in these sites are Caddo trade wares from the Red River basin to the south. Since the Fort Coffee phase sites appear to have been occupied until only ca. A.D. 1660, it is probable that the Womack Engraved vessels found there-if they are indeed stylistically the same as Womack Engraved vessels found on East Texas Caddo sites - must date at the very end of the Fort Coffee phase settlement of this locale and perhaps prior to the beginning of the Womack phase. In any case, there does not appear to be any association between this protohistoric Wichita group and the manufacture of Womack Engraved on the Red River and other parts of East Texas. Instead, Womack Engraved was already being manufactured by that time among several Caddo groups in the upper Sabine River, Big Cypress, and Sulphur River basins.

In summary, then, the Womack site was a large and important ancestral Caddo settlement on the upper Red River during the Womack phase, and this occupation (which followed well after several others extending back to ca. 10,000 years B.P.), was from ca. A.D. 1700-1730. This occupation was characterized by midden deposits, probable house features, and several cemeteries, along with a robust chipped stone assemblage focused on the hunting and processing of large game animals for their hides and meat, and a diverse ceramic tradition with plain ware, fine ware, and utility ware vessels and sherds; Womack Engraved vessels and sherds are the iconic archaeological symbol of the Womack phase in East Texas.

\section{ACKNOWLEDGMENTS}

I would like to thank Jonathan Jarvis at TARL for facilitating the study of the collections and records from the Womack site held by TARL. I also thank Lance Trask for preparing the many figures in this article, and Robert Z. Selden Jr. for providing the calibration of the two radiocarbon dates from the site. 


\section{REFERENCES CITED}

Baugh, T. G.

2009 Protohistoric Kirikir ' $i$-s Societies on the Central and Southern Plains. Oklahoma Anthropological Society Bulletin 57:15-59.

Bell, R. E., E. B. Jelks, and W. W. Newcomb (assemblers)

1967 A Pilot Study of Wichita Indian Archeology and Ethnohistory. Final report for Grant GS-964, National Science Foundation, Washington, D.C.

Brown, J. A.

1996 The Spiro Ceremonial Center. The Archaeology of Arkansas Valley Caddoan Culture in Eastern Oklahoma. 2 Vols. Memoir No. 29. Museum of Anthropology, University of Michigan, Ann Arbor.

Cast, R., T. K. Perttula, B. Gonzalez, and B. Nelson

2006 Documentation of Caddo Ceramic Vessels from 41WD60, Wood County, Texas. Historic Preservation Program, Caddo Nation of Oklahoma, Binger.

Duffield, L. F. and E. B. Jelks

1961 The Pearson Site: A Historic Indian Site at Iron Bridge Reservoir, Rains County, Texas. Archaeology Series No. 4. Department of Anthropology, The University of Texas at Austin.

Duncan, M., L. Neal, D. Shockley, D. Wyckoff, M. Sullivan, and L. M. Sullivan

2007 Southern Plains Lithics: The Small Points. Special Bulletin No. 26. Oklahoma Anthropological Society, Oklahoma City.

Flynn, P.

1976 A Study of Red-Filmed Pottery from the Clement Site (Mc-8), McCurtain County, Oklahoma. Bulletin of the Oklahoma Anthropological Society 25:127-134.

Hamilton, T. M.

1968 Early Indian Trade Guns: 1625-1775. Contributions No. 3. Museum of the Great Plains, Lawton, Oklahoma.

1979 Guns, Gunflints, Balls and Shot. In Tunica Treasure, by J. P. Brain, pp. 206-216. Papers of the Peabody Museum of Archaeology and Ethnology, Volume 71. Harvard University, Cambridge, Massachusetts.

Harris, R. K.

1946 An Interesting Copper Article from Garrett's Bluff. The Record 5(1):7. Dallas Archeological Society, Dallas.

Harris, R. K. and I. M. Harris

1967 Trade Beads, Projectile Points, and Knives. In A Pilot Study of Wichita Indian Archeology and Ethnohistory, assembled by R. E. Bell, E. B. Jelks, and W. W. Newcomb, pp. 129-162. Final report for Grant GS-964, National Science Foundation, Washington, D.C.

Harris, R. K., I. M. Harris, J. C. Blaine, and J. Blaine

1965 A Preliminary Archeological and Documentary Study of the Womack Site, Lamar County, Texas. Bulletin of the Texas Archeological Society 36:287-365.

Hoffman, M. P.

1967 Ceramic Pipe Style Chronology Along the Red River Drainage in Southwestern Arkansas. The Arkansas Archeologist 8(1):4-14.

Jackson, A. T.

1933 Some Pipes of East Texas. Bulletin of the Texas Archeological and Paleontological Society 5:69-86. 
Jelks, E. B. (editor)

1967 The Gilbert Site: A Norteno Focus Site in Northeast Texas. Bulletin of the Texas Archeological Society $37: 1-248$.

Krieger, A. D.

2000 The Pottery of the Sanders Farm. In The 1931 Excavations at the Sanders Site, Lamar County, Texas: Notes on the Fieldwork, Human Osteology, and Ceramics, by A. T. Jackson, M. S. Goldstein, and A. D. Krieger, pp. 131-144. Archival Series 2. Texas Archeological Research Laboratory, The University of Texas at Austin.

Pearce, J. E. and A. T. Jackson

1931 Field Notes: Excavation on the H. E. Womack Farm, Lamar County, Texas, August 29, 1931 to September 4, 1931. MS on file, Texas Archeological Research Laboratory, The University of Texas at Austin.

Perttula, T. K.

2007 Inverted Rim Engraved Vessels in Protohistoric and Early Historic Caddo Sites in Parts of Northeast Texas. Journal of Northeast Texas Archaeology 26:136-144.

2009 The Archaeology of the 16th and 17th Century Caddo in the Post Oak Savannah of Northeast Texas: the Tuinier Farm (41HP237), R. A. Watkins (41HP238), and Anglin (41HP240) Sites in the Stouts Creek Basin, Hopkins County, Texas. Journal of Northeast Texas Archaeology 30:1-132.

2011 The Ceramic Artifacts from the Lang Pasture Site (41AN38) and the Place of the Site within an Upper Neches River Basin Caddo Ceramic Tradition. In Archeological Investigations at the Lang Pasture Site (41AN38) in the Upper Neches River Basin of East Texas, assembled and edited by T. K. Perttula, D. B. Kelley, and R. A. Ricklis, pp. 145-320. Archeological Studies Program Report No. 129, Texas Department of Transportation, Environmental Affairs Division, Austin.

2013 Caddo Ceramics in East Texas. Bulletin of the Texas Archeological Society 84:181-212.

2014 Archaeological Studies of the Hatchel Site (41BW3) on the Red River in Bowie County, Texas. Special Publication No. 23. Friends of Northeast Texas Archaeology, Austin and Pittsburg.

2015 East Texas Caddo Ceramic Sherd Database. Journal of Northeast Texas Archaeology 51, in press.

Perttula, T. K. and B. Nelson

2007 The Gum Creek Cluster: Protohistoric Caddo Sites in the Little Cypress Creek Basin, ca. A.D. 16701720. Journal of Northeast Texas Archaeology 26:128-135.

Perttula, T. K., P. S. Marceaux, B. Nelson, and M. Walters

2015a Caddo Ceramic Vessels from Sites in the Upper Neches River Basin of East Texas, Anderson and Cherokee Counties, Texas. Special Publication No. 37. Friends of Northeast Texas Archaeology, Austin and Pittsburg.

Perttula, T. K., B. Nelson, M. Walters, and R. Z. Selden Jr.

2015b The Sanders Site (41LR2): A Middle to Historic Caddo Settlement and Mound Center on the Red River in Lamar County, Texas. Journal of Northeast Texas Archaeology 50, in press.

Perttula, T. K., M. Walters, and B. Nelson

2012 Little Cypress Creek Basin Archaeology: Six Late Caddo Period Cemeteries in Upshur County, Texas. Special Publication No. 22. Friends of Northeast Texas Archaeology, Austin and Pittsburg.

Rodning, C. B.

2014 Cherokee Towns and Calumet Ceremonialism in Eastern North America. American Antiquity 79(3):425443.

Rogers, J. D.

2006 Chronology and the Demise of Chiefdoms: Eastern Oklahoma in the Sixteenth and Seventeenth Centuries. Southeastern Archaeology 25(1):20-28. 
Rohrbaugh, C. L.

2012 Spiro and Fort Coffee Phases: Changing Cultural Complexes of the Caddoan Area. Memoir 16. Oklahoma Anthropological Society, Norman.

Schambach, F. F.

2002 Fourche Maline: A Woodland Period Culture of the Trans-Mississippi South. In The Woodland Southeast, edited by D. G. Anderson and R. C. Mainfort, pp. 91-112. University of Alabama Press, Tuscaloosa.

Smith, J. E. II

1993 The Vinson Site (41LT1): A Norteno Focus Indian Village in Limestone County, Texas. Bulletin of the Texas Archeological Society 64:65-162.

Stephenson, R. L.

1970 Archeological Investigations in the Whitney Reservoir Area, Central Texas. Bulletin of the Texas Archeological Society 41:37-277.

Story, D. A., B. Barber, E. Cobb, H. Cobb, R. Coleman, K. Gilmore, R. K. Harris, and N. Hoffrichter

1967 Pottery Vessels. In “The Gilbert Site: A Norteno Focus Site in Northeast Texas," edited by E. B. Jelks. Bulletin of the Texas Archeological Society 37:112-187.

Todd, J.

2010 Two Catlinite Pipe Fragments from the Womack Site, Lamar County, Texas. Caddo Archeology Journal 20:139-142.

Turner, R. L.

2006 Hematite Axes of Northeast Texas. Bulletin of the Texas Archeological Society 77:1-32.

Webb, C. H.

1959 The Belcher Mound: A Stratified Caddoan Site in Caddo Parish, Louisiana. Memoirs No. 16. Society for American Archaeology, Salt Lake City. 